\title{
Creating a Better Place: Physical Improvements in Academic Libraries, 1995-2002
}

\section{Harold B. Shill and Shawn Tonner}

\begin{abstract}
Many academic institutions have benefited from new, expanded, renovated, or reconfigured facilities since the mid-1990s. Given current concerns about the future of the physical library and the nature of space needs, it is important to know what improvements have been made in recent facility projects and what impact these improvements have had on use of the physical library. Based on findings from a survey of 354 academic libraries, this article describes the types of projects undertaken and the kinds of improvements provided. A companion article describing the impact of these improvements on usage of the physical facility is in preparation.
\end{abstract}

\section{Background}

Academic librarians have debated the future of "the library as place" for more than twenty years. Technological advances and shifting institutional perceptions have given increasing urgency to this discussion in recent years. The Association of Research Libraries (ARL) and OCLC cosponsored a two-day Strategic Issues Forum, "Future Library Architecture: Conception, Design and Use of Library Space," in February 2002 to focus attention on the strategic importance of physical space issues. The LibQual+ assessment instrument (www.libqual.org) includes five core questions on the quality of physical library facilities as perceived by users.

More than four hundred academic library facility projects-new libraries, additions to existing buildings, and renovations-have been completed since 1995 .
More than fifty other projects are currently under construction or in the design stage. Still other institutions are pursuing funding to build new libraries or upgrade existing facilities to meet space, technology, and user needs.

\section{Environmental Factors}

Despite that flurry of building activity, the central importance of library facilities in higher education planning is no longer assured. Academic administrators confront a succession of difficult decisions in a constrained fiscal environment.

Expanding technology needs have become the new "bottomless pit" of the twenty-first century, with overall expenditures projected to reach $\$ 5.2$ billion nationwide in 2003-2004. ${ }^{1,2}$ In addition, new student facilities and services are needed to attract and retain students. ${ }^{3}$ Aging,

Harold B. Shill is Director of Capital College Libraries at Penn State Harrisburg and Penn State Schuylkill; e-mail: hbs2@psu.edu. Shawn Tonner is Director of the Hill Freeman Library E Spruill Learning Center at Reinhardt College; e-mail: sct@reinhardt.edu. 
"legacy" buildings lack the infrastructure required to permit flexible use of technology in classroom, lab, and student residence facilities. ${ }^{4}$ Deferred maintenance of physical facilities has reached crisis proportions in some institutions. ${ }^{5}$ Reduced state funding and eroding endowments have forced many colleges into doubledigit tuition increases to cover operating costs. $^{6}$

At the same time, academic libraries have provided a steadily expanding array of electronic resources and services. By making these collections and services available to remote users, librarians have made it less necessary for faculty and students to visit the physical library to address many of their research and information requirements.

Given the availability of off-site, 24/7 access to subscription databases and Internet resources, some institutions are questioning the need for existing library space, much less new or expanded library facilities. At Rice University, a planned replacement for the central library has been postponed for a decade "until the electronic thing sorts itself out," according to its provost. ${ }^{7}$ Other institutions have deferred building projects for a variety of reasons in recent years. ${ }^{8}$

\section{Challenges: Old and New}

Questions about the viability of physical libraries are hardly new. Dismissing complaints about reductions in California public library hours, Proposition 13 tax cut advocate Howard Jarvis retorted, "Nobody ever went there since the Civil War, so I don't know what all the fuss is about." ${ }^{\prime 9}$ In the mid-1990s, a college administrator announced that the new California State University-Monterey Bay (CSU-MB) campus would open without a physical library and then retracted the statement following adverse reactions from faculty. ${ }^{10} \mathrm{CSU}-\mathrm{MB}$ is now planning to open a 200,000 square foot library in 2006-2007.11

More recently, the Pew Internet and American Life Project reported that 71 percent of all high school students relied on the Internet as the primary source for their most recent research project. ${ }^{12}$ In his studies of Generation Y students, Stephen Merritt has suggested that their fascination with technology may discourage physical library use because the library is perceived as a pretechnology institution. ${ }^{13}$

\section{Declining Use?}

Librarians also have been concerned about declines in traditional usage statistics. Association of Research Libraries (ARL) members experienced median declines of 21 percent in circulation and 31 percent in reference activity between 1995 and 2001. ${ }^{14}$ Association of Academic Health Sciences Libraries (AAHSL) members reported aggregate exit gate count and circulation declines of 8.3 and 25.7 percent, respectively, between 1996-1997, and 2000-2001. ${ }^{15}$

Although investments in-and use of-electronic resources have increased significantly in recent years, use of those materials is not place bound. Academic administrators are becoming increasingly aware of declines in traditional usage statistics. And as Donald E. Riggs has noted, "Despite its oversimplification, the belief that 'everything is going to be online' influences decision makers not to fund requests for new libraries." ${ }^{16}$ Apart from citing impending shelf space exhaustion, librarians have had difficulty arguing for major facility improvements where usage of the physical "place" is diminishing. Moreover, declining usage undermines the justification for existing physical facilities.

Scott Carlson's controversial Chronicle of Higher Education article, "The Deserted Library," focused many administrators' attention on the declining use of many library facilities in November $2001 .{ }^{17} \mathrm{Al}$ though Carlson's article cites both significant declines and major increases in building usage, its subheading, "Why Students Are Abandoning the Library for Bookstores and Starbucks," implies that other facilities have supplanted the library as preferred research locations. A digitally 
engineered photograph showing student "ghosts" vanishing from a nearly empty library reinforces the impression of a growing trend away from use of the physical facility.

Given the almost universal readership of the Chronicle by higher education administrators, Carlson's article strengthened a growing perception, fueled by expanding Internet use, that physical libraries are becoming less essential in the educational experience of students. Although two recent articles in University Business documented significant usage increases in new libraries at Illinois Wesleyan University and Williams College's Schow Science Library, this publication reaches far fewer academic decision makers than the Chronicle does. ${ }^{18}$ Alice Harrison Bahr has identified ten arguments justifying library buildings in a recent College $\mathcal{E} R e-$ search Library News article..$^{19}$ However, library science publications are not widely read by nonlibrarian administrators.

\section{Increased Usage}

There is anecdotal evidence that investments in new, enlarged, or renovated library facilities are associated with significant increases in student usage, even with abundant Internet and electronic database resources accessible from nonlibrary locations. Experienced planners on the Library Administration and Management Association (LAMA) Facility Planning Discussion Group estimate that usage in new buildings typically increases 30 to 70 percent. The King's College Library at Western Ontario University experienced a 420 percent facility usage increase after opening a new library in 1997. ${ }^{20}$ After opening a new facility on January 17 , 2001, St. Martin's College reported a similar gate count upsurge, with usage rising from 56,964 persons in 1999-2000 to 171,095 users in 2001-2002. ${ }^{21}$ A recent article in Library Journal reported usage increases of 13.8 percent in 2001-2002, three years after a new Loyola University (New Orleans) library opened. ${ }^{22}$

However, this evidence has not been supported by systematic empirical inves- tigation. Moreover, it is unclear whether specific building enhancements lead to particular types of usage increases. Lacking validated evidence of any facility improvement-library usage relationship, librarians increasingly fight an uphill battle to secure funding for facilities projects of any type in an increasingly technologyfocused, decentralized, and fiscally constrained environment.

Clearly, there is still significant support in higher education for a physical library, whether as an academic asset or for purely symbolic reasons. However, in an era of escalating technology costs and competing institutional claims for limited capital project resources, it is reasonable for academic administrators to ask whether enhanced library facilities will provide educational benefits sufficient to justify the investment of scarce resources.

\section{Research Questions}

To plan appropriately when faced with library space issues, it is important that administrators and librarians understand the purposes for which libraries are used and the conditions under which they are being used. As collection growth strains existing stack capacity and technology is infused ubiquitously into the teaching and learning environments, it is similarly important to know (1) whether capital investments in improved library facilities contribute to increased student usage, (2) what types of improvements correlate most closely with significant increases in usage, and (3) whether usage continues to increase after the "novelty" of a recently opened building is gone.

The following study reports findings from a Web survey of 357 academic libraries completing a new building, an expansion and renovation project, a renovation, an addition, or a major space reconfiguration between 1995 and 2002. Because decentralized network access and widespread ownership of laptop computers are relatively recent phenomena, pre-1995 projects were excluded. The 1995 starting year was selected to permit a focus on facilities where emergent technology 
needs should have been a key planning consideration. The survey addressed four major research questions:

1. What types of improvements have been done in recent library projects, and how extensively have they been done?

2. Do improved buildings experience significantly greater usage than libraries not undergoing major physical improvements?

3. What types of improvements are most closely associated with major increases in usage, and which types are more marginal?

4. Are initial postproject increases in usage sustained over time, or does usage diminish after the "novelty" of a new facility has worn off?

The answers to these questions should help higher education administrators determine whether investments in improved library facilities are merited. The findings also should help librarians, architects, and physical plant managers plan library buildings most likely to attract future students and to address their evolving educational and social needs.

This article focuses on question 1 , the types of improvements included in recent projects completed between 1995 and 2002. It is important that librarians, architects, and institutional facility planners know what types of features have been included in recent projects. Questions 2 through 4 will be addressed in a companion article.

\section{Study Significance}

The current study draws on existing knowledge of academic library use, library users, space planning, and the "library as place." In turn, its findings should have an impact on both practice and research in each of these areas.

\section{Use and Users}

There is a substantial body of research on user behavior, including use of physical library facilities, in the literature. Michael K. Buckland addressed the impact of open stacks on collection use in Book Availability and the Library User in the 1970s. ${ }^{23}$ Allen
Kent and his colleagues reported in 1979 that many books in research library collections go unused for long periods of time. ${ }^{24}$ Charles B. Osburn examined the implications for libraries of changing research patterns in the social sciences, humanities, and sciences. ${ }^{25}$

More recent studies have focused on changing usage patterns as the result of the Internet becoming an established information resource. Ethelene Whitmire and Ruth C. Shoge have examined the relationship between students' ethnic and racial characteristics and their use of library facilities. ${ }^{26}$ John Lubans Jr. has studied evolving patterns of Internet use among undergraduates at Duke University. ${ }^{27}$ Reports from the Pew Internet \& American Life Project have examined Internet and technology use among high school and college students. ${ }^{28}$

Researchers in economics, psychology, and higher education administration have examined factors contributing to the use or nonuse of academic libraries. ${ }^{29}$ Other recent studies have focused on disciplinary information-searching patterns, student seating preferences in libraries, the use of print resources, student Web use in research, and library anxiety, among other topics. ${ }^{30-34}$

A long-anticipated Council on Library and Information Resources study (known as the Outsell study, reflecting the name of the consulting firm conducting it) focused on student and faculty use of information resources from classrooms, offices, libraries, computer labs, and residential locations. ${ }^{35}$ This study found that respondents' information use and perceptions of libraries varied across disciplines, by type of institution, and among students at various levels of study and faculty. ${ }^{36}$ A recent OCLC white paper also has addressed student information-seeking behavior. ${ }^{37}$

\section{Space Planning}

In addition, there is an ample and growing literature on library facilities and space planning. The facilities-focused contributions are generally practical and 
heuristic in nature, focusing on the planning process, elements of good design, key building features, space requirements for people and collections, incorporation of technology, HVAC systems, furniture, lighting, collection moving, and other aspects of facility planning and occupancy. $^{38}$

Some titles, such as Richard J. Bazillion and Connie L. Braun's Academic Libraries as High-Tech Gateways, provide superb guidance for blending technology into a welcoming learning environment. ${ }^{39}$ Michael J. Crosbie and Damon D. Hickey's When Change Is Set in Stone delivers visual evidence of successful solutions in varied institutional environments. ${ }^{40}$ Philip D. Leighton and David C. Weber's Planning Academic and Research Library Buildings remains useful, despite its 700-page length. ${ }^{41}$ William W. Sannwald's Checklist of Library Building Design Considerations remains a unique, indispensable tool addressing the entire spectrum of facility planning issues. ${ }^{42}$

The annual architectural issues of $\mathrm{Li}$ brary Journal (December) and American Libraries (April) document many library projects completed during the preceding year, plus architectural photographs from selected facilities and AIA/ALA awardwinning libraries. ${ }^{43}$ Articles on postoccupancy evaluation are beginning to enter the library science literature. ${ }^{44}$

Many recent articles have focused on the development of Information Commons facilities within existing or new libraries. ${ }^{45}$ Other treatments have focused on compliance with the Americans with Disabilities Act (ADA). ${ }^{46}$ Some books and articles have provided case studies of specific library projects. ${ }^{47}$ Many other books and periodical articles share knowledge about building planning in general or address specific facility issues. ${ }^{48}$

\section{The Library as Place}

Ironically, given the large cost of new or improved facilities, there are no systematic, empirical studies documenting the impact of enhanced library buildings on student usage of the physical library.
Lacking such evidence, librarians must make an overwhelming case for current facility inadequacy or rely on limited, anecdotal evidence of postconstruction usage increases to justify a new building or major improvements to an existing facility. Although anecdotal evidence is useful, it is unlikely to be compelling for academic administrators confronted with multiple demands on limited resources for capital improvements.

With increasing student reliance on the Internet and electronic resources, along with growing administrator awareness of declining usage patterns in some physical facilities, it is important that a verifiable relationship between capital investments and student usage be demonstrated. The current study is intended to provide valid, cross-institutional evidence of the impact of facility improvements on both overall library usage and specific types of usage. Without such clear evidence, academic librarians will be hard-pressed to make the case for future enhancements.

There has been some disagreement within the academic community about the significance of the physical library. F. W. Lancaster's Toward Paperless Information Systems and similar writings in the $1960 \mathrm{~s}$ and 1970s forecasted the marginalization of print collections. ${ }^{49} \mathrm{Sev}$ eral nonlibrary writers have applauded the decline of the physical library as resources become digitized and available on the Internet. ${ }^{50}$ Some virtual library advocates have projected a diminishing need for collection and user space as electronic resources become increasingly central in student research and scholarly communication. ${ }^{51}$

Michael Gorman and Walt Crawford have argued eloquently in several books and articles that the "library as place" serves a number of socially valuable roles beyond that of providing a physical location for books and librarians. ${ }^{52}$ Neil Gershenfeld of the MIT Media Lab has noted that materials transmitted on the printed page are more user-friendly in many ways than computer-delivered in- 
formation. ${ }^{53}$ Sam Demas and Jeffrey Scherer have pointed out that new service structures can sharply increase the use of existing buildings. ${ }^{54}$

Whatever the relative long-term value of the physical library may be (and these investigators share Gorman's view that the physical library matters profoundly), the future willingness of academic administrators to invest in library facility improvements is likely to depend heavily on the library's ability to demonstrate that:

- Improved facilities will significantly increase building usage.

- Greater use of the library building will improve educational outcomes.

- The library knows what types of facility enhancements are most likely to produce the desired usage and educational results.

\section{Study Design and Methodology}

Planning for this project began in summer 2001 when the principal investigator defined major research issues, conducted a preliminary literature review, and drafted a sabbatical leave proposal. The leave proposal was submitted for review by sabbatical leave committees and administrators in September 2001. The leave request was approved in January 2002 and scheduled for January-June 2003. A \$2,000 Penn State Libraries Faculty Organization (LFO) research grant was awarded to support the project.

To conduct the study, it was necessary to (1) identify an appropriate sample or population of enhanced libraries matching study inclusion criteria and (2) generate a survey instrument to elicit desired facility and usage data from respondents. The selection of a study population and survey design proceeded simultaneously in summer and fall 2002.

\section{Survey Population}

There is no comprehensive source identifying library building projects, but BetteLee Fox's annual compilations of academic and public library projects for Library Journal's architectural issue provides an extensive listing. ${ }^{55}$ Her listings, which ex- tend back to the early 1980s, include most known academic library projects. This listing also is published each year in the Bowker Annual of Library and Book Trade Information.

An initial review of annual Library Journal listings from 1995 to 2002 identified 197 academic library projects meeting the size criteria for inclusion in this study. The investigators reviewed annual architectural issues (April) of American Libraries, along with articles announcing project funding, groundbreakings, and dedications in College $\mathcal{E}$ Research Libraries News, LJ Hotline, and other publications to identify additional projects completed during this time span.

The investigators also utilized informal communication channels extensively to identify academic library projects not publicized in the standard sources. Many projects were identified through informal communications with LAMA/BES members and leading architects, solicitations on LAMA/BES and Community College Libraries listservs, and existing LAMA/ BES project compilations. Logan Ludwig of the AAHSL provided a listing of recent medical library projects. James Fox of the Penn State Dickinson School of Law provided similar data for law libraries. Finally, a Google ${ }^{\mathrm{TM}}$ Web search was conducted to identify additional projects not located through other media.

Several criteria were established to determine which projects to include in the study. First, the study was focused on projects completed between 1995 and 2002. As noted earlier, it was reasoned that library facilities completed during this time frame should have been designed to accommodate the growth in electronic resources and increasing student ownership of personal computers.

Second, a 20,000-square-foot minimum size for the project area was established to exclude minor renovations unlikely to have a significant effect on usage. Some smaller community college libraries were excluded from the study by this criterion, but the response level from two-year institutions was sufficient $(n=20)$ to allow 
the researchers to reach conclusions about enhanced facility features, quality, and postproject usage levels in two-year institutions.

Off-site storage facilities were excluded because they generally are closed to the public, thereby precluding usage measurements. Renovations focusing on offices and other nonpublic areas were similarly eliminated from consideration. Several facilities identified in the 1995 Library Journal listing were removed from the study population when respondents indicated that actual completion had occurred in 1994.

In some cases (new academic institution, new medical library without a prior equivalent facility, lack of data on preproject usage), libraries were included despite the impossibility of meaningful before-and-after usage comparisons because their responses would provide useful data describing facility features included in recent projects.

The number of library projects identified as meeting study criteria far exceeded the total number of improved academic libraries listed in other sources. It is believed that the project listing closely approximates the total number of projects completed during the study time frame and meeting inclusion criteria. Because the study population reasonably approximates the overall population of academic library projects completed during the 1995-2002 period, sampling to control for possible selection bias was unnecessary.

In addition to yielding a study population for this investigation, the listing of 1995-2002 projects will be expanded into an Academic Library Projects Database. This database should help facility planners identify appropriate, completed libraries for preproject benchmarking. A LAMA/BES committee will expand the database into a more comprehensive resource including academic, public, school, and special library projects.

\section{Survey Design}

Design of the survey instrument was begun in summer 2002. Following a recom- mendation from Penn State Harrisburg's Survey Research Center (SRC), the investigators decided to conduct a Web survey rather than a mailed survey. The Web survey allowed direct e-mail communication with targeted respondents, eliminated response coding time and costs, and permitted bulk data transfer into statistical software packages for data manipulation. Arrangements were made to work with Penn State's Social Sciences Research Institute (SSRI) to program and administer the Web survey.

The draft survey was submitted to Penn State's Institutional Review Board (IRB) for a Human Subjects Clearance Review in October 2002. Approval to conduct a confidential survey was granted by the IRB on November 30, 2002. Respondents were to be advised that the survey would be confidential and were given an opportunity to agree to participate, decline, or ask questions. The IRB directed that data files from this project be destroyed by November 23, 2003, to protect the respondents.

The survey contained sixty-eight factual, pre- and postproject comparison and open-ended questions designed to elicit descriptive and usage data about improved library facilities. Seven types of questions-six about facility and institutional characteristics and one about usage levels-were asked. It was recognized that the length of the survey imposed a significant respondent burden, and prospective participants were advised that completion would require thirty to fortyfive minutes when several types of quantitative data had been assembled.

\section{Questions Asked}

Initially, respondents were asked to provide data about key institutional characteristics, such as public or private affiliation and special missions (women's college, historically black institution, etc.). Questions about student body characteristics (percent of commuting students, computer ownership requirements, etc.) were asked to permit the examination of possible relationships between those at- 
tributes and facility usage patterns in the companion article. The investigators separately identified appropriate institutional classifications (associate, baccalaureate, law, medical, etc.) for each library from the Carnegie Foundation for the Advancement of Teaching Web site (www.carnegiefoundation.org).

The survey next addressed project-specific variables, such as type of project (new building, addition, addition/renovation, new library within a multipurpose facility), completion date, project cost, and architectural firms responsible for design. These questions provided summary data about the types of facility projects being completed during the study period. They also permitted the investigators to determine whether the number of projects increased, declined, or remained stable during the 1995-2002 period. In addition, these questions provided data necessary for cross-tabulation with other facility and institutional characteristics.

Assuming that physical location on campus might affect usage levels, the investigators asked whether the enhanced library had a central, peripheral, or neutral location. In addition, the survey asked whether the improved library was located within a quarter mile of student parking lots, residence units, classroom buildings, the student center, and recreational facilities.

The third set of questions contrasted the pre- and postproject libraries in order to identify the nature and extent of improvements made. The investigators were particularly interested in learning what technology, collaborative learning, and instruction lab enhancements had been made in recent facility projects. These data enabled the investigators to summarize the major facility changes resulting from these projects, thereby advancing existing knowledge about project improvements beyond the level of anecdotal evidence.

To contrast the preproject and enhanced facilities and to permit summary conclusions about the type and extent of enhancements, this section included before-and-after comparison questions on:
- square footage (gross and assignable);

- percent of facility designated for library functions;

- number of data ports;

- number of general use seats;

- number of public service points;

- number of public access workstations;

- number of group study rooms;

- number of group study room seats;

- number of workstations in instruction labs;

- type of wiring;

- use of wireless systems;

- percent of seats with wired network access;

- percent of seats with wireless network access;

- hours of operation (weekly).

Additional questions in this section requested data on food and drink policies, presence of artwork in public areas, primary floor covering (carpet, tile, etc.), primary floor and wall colors, and extended-hour access.

Fourth, the survey asked questions about the presence of nonlibrary facilities within the library building, both before and after the project. Based on their own knowledge and prior site visits, the investigators expected to find a trend toward inclusion of nonlibrary services, particularly where a new building or addition had been constructed. Questions in this section were designed to identify the types of nonlibrary facilities included and to determine whether their presence was more extensive in the postproject libraries than it had been before the project.

The survey asked specifically whether the library building included a general computer lab, a snack bar or cafe, classrooms, seminar rooms, a conference room, an auditorium, a multimedia production center, an art gallery, a writing lab, a bookstore, a research institute, or an educational technology center. An open-ended question permitted respondents to identify other types of facilities within the physical confines of the library.

Each library also was asked to compare facility quality along ten dimensions, plus the overall ambience of the library, before 
and after the project. Quality assessments for the following variables were requested:

- layout/ease of navigation;

- location of service points;

- instruction lab or e-classroom;

- user seating/work space;

- collection storage;

- telecommunication network;

- artificial lighting;

- natural lighting;

- HVAC.

The responses in this section were expected to indicate the degree of improvement occurring in these facility areas as a result of the project. In addition, these questions were designed to identify building components where architects had been most and least successful in enhancing the library facility. Finally, respondents were asked to assess their overall satisfaction with the postproject library facility and to identify any further strengths or deficiencies in the pre- and postproject libraries.

Several collection variables were included to determine what provisions had been made for postproject collection growth and access. Respondents were asked to identify an approximate date when their postproject shelving capacity would be exhausted, the percentage of the collection stored in compact shelving, and the percentage stored off-site. The shelf space exhaustion question was intended to determine how effectively the participating libraries had planned for print collection growth. Responses to this question also could reflect libraries' future plans for reliance on electronic resources.

The compact storage question was designed to determine how extensively compact storage is used to extend the library's capacity to provide on-site access to materials. Postproject reliance on offsite storage indicated that the library had not placed its entire collection under one roof, whether as a result of inadequate funding, poor planning, or a conscious choice to use remote facilities to store lower-use items.

Finally, the survey requested data on four usage variables - exit gate count, total circulation, in-house collection use, and reference transactions-from 1993-1994 through December 2002. The resulting responses provided the "dependent variables" data for the before-and-after usage comparison reported in the companion article.

\section{Study Conduct}

By mid-January 2003, the investigators had identified 384 academic library projects appearing to meet study inclusion criteria through this combination of search strategies. An initial invitation message was e-mailed to all 384 libraries initially identified on January 20, 2003. That communication explained the project, invited voluntary participation, provided a statement of research subject protections, gave prospective respondents a unique password for their libraries, and offered them the opportunity to ask questions about the survey.

Following initial respondent feedback, twenty-seven projects were excluded from the study, reducing the number of qualifying libraries to 357 . The excluded libraries did not meet project criteria, such as facility size or completion during the 1995-2002 study period.

Initial responses and several participant questions were received on the first day of the survey. Several respondents indicated a high level of interest in the project, noting that the findings would provide valuable knowledge for academic librarians and higher education administrators.

E-mail reminders were sent on February 10 and February 24. Respondents were asked to complete the survey by March 6. The investigators sent targeted reminder messages to specific libraries after that date. Some respondents experienced difficulty in viewing completed responses and/or submitting the last part of the survey, so the project investigators provided e-mail assistance to help those individuals participate fully.

Data analysis began on March 18, with data from 179 responding libraries. The responses from each participating library 
were coded automatically and stored on a database created by the SSRI. The responses then were exported from the SSRI database into an Excel spreadsheet for initial analysis and data manipulation. Three additional libraries responded after the data analysis began, expanding the number of participating libraries to 182 and providing a 51 percent overall response rate for the survey.

Specific findings about pre- and postproject library features are reported below in the following sections: (1) general project characteristics; (2) technology; (3) user space; (4) collection provisions; (5) interior features; (6) nonlibrary facilities; and (7) facility quality. A final section summarizes the major findings about facility improvement, indicates their significance for academic library planning, and suggests directions for future research.

\section{Findings: General Project Characteristics}

To secure an overview of general trends in recent academic library building projects, respondents were asked questions about the type of project done at their libraries, completion dates, public/ private affiliation, facility size, the library's campus location, and shared usage with other campus operations. The investigators also determined the Carnegie classification for each library's host institution. The findings from those questions are described in this section.

\section{Project Types}

Respondents were asked to place their library project into one of five categories:

(1) new stand-alone library; (2) new library in multipurpose facility, (3) addition and renovation; (4) addition only; or (5) other type of project. The "new / multipurpose" category was created to reflect possible differences in libraries located within a larger facility, such as a science branch library in a science building. The "other" category included renovations, reconfigurations, and "re-purposing" of existing facilities without any new space added. For statistical analysis, renovations were separated from the remaining types of "other" projects through respondents' descriptions of their projects in open-ended questions. The number of libraries in each category is shown in table 1.

Fox's 1995-2002 annual summaries documented 197 completed academic library projects, including off-site storage facilities, meeting this study's minimum size criterion of 20,000 square feet. Using slightly different categories (new, addition and renovation, renovation only), Fox identified ninety-one new academic libraries, seventy-six addition and renovation projects, twenty-nine renovation-only projects, and one addition-only facility completed during this eight-year period.

The current study's "new" and "new, multipurpose" categories were combined temporarily for comparison with Fox's data to determine whether there were any differences in the distribution of project types found. Of the 182 responding libraries, 43.1 percent fit into Fox's "new" category, yet Fox found that 46.2 percent of the libraries answering her annual Library Journal surveys were new. Similarly, 38.6 percent of Fox's libraries were placed in the "addition and renovation" category, whereas 42.0 


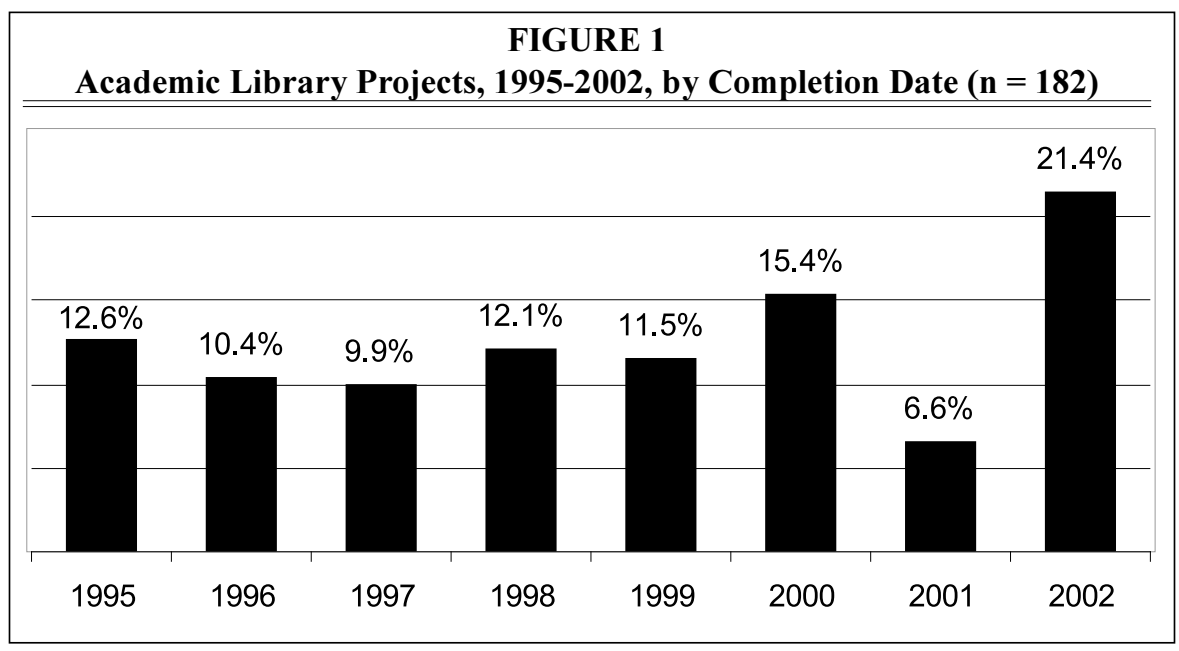

percent of the responses in the current survey matched that category. Finally, 14.7 percent of Fox's libraries and 12.1 percent of the libraries completing the current survey could reasonably be placed in the "renovation-only" category.

The closely similar distribution of project type responses confirms that the current study is consistent with known patterns of academic library improvement. This finding further confirms that the use of multiple strategies to identify recent academic library projects did not introduce any unintended bias into the current study.

\section{Completion Pattern}

Many library leaders feel that the number of facilities projects has declined in recent years. Although it likely is becoming more difficult to argue the case for new or expanded physical facilities, the impression of a long-term facility project decline is not supported by the survey findings. As shown in figure 1, the number of completed projects remained relatively stable from 1995 through 2000 but declined significantly in 2001. However, the number of project completions then rebounded to its highest level during the entire study period in 2002.

The 2002 increase in project completions does not constitute evidence of a long-term trend toward greater institutional investment in library projects.
However, that finding does confirm that overall building activity has not declined. Because a number of new libraries (Marquette University, San Jose State University, Arcadia University, University of Georgia Student Learning Center, among others) will open during the 20032004 academic year, it appears that many libraries are making an effective case for facility improvements despite fiscal constraints, internal competition for limited funds, and technological changes in the information environment.

\section{Public and Private Projects}

The Carnegie Foundation for the Advancement of Teaching lists classifications for 3,941 higher education institutions on its Web site. Public institutions comprised 41.7 percent of the institutions listed, and private nonprofit and private for-profit institutions accounted for 42.7 and 15.6 percent, respectively, of the institutions listed. ${ }^{56}$

Not surprisingly, the current study did not identify any new or improved library facilities at for-profit institutions. To compare the extent of building activity and subsequent usage changes in public and private, nonprofit institutions, participants were asked to indicate their institution type. Given their relative proportion in the overall institutional population, 51 percent of the library projects 
would be expected to occur in private colleges if the improvements were spread evenly among all institutions. However, 64 percent of the responding libraries were in public institutions, 35 percent were in private institutions, and one percent was categorized as "other."

This apparent difference in construction activity may be somewhat misleading because 63.6 percent of the Carnegie doctoral/research universities are public institutions and several libraries in this category (University of Maryland, Ohio State University, University of Minnesota, Penn State University) completed multiple facility projects between 1995 and 2002. According to the Carnegie Foundation, private control is most prevalent in baccalaureate colleges $(82.3 \%)$ and specialized institutions $(77.4 \%)$, where there is typically only one library on campus. In contrast, most associate degree institutions $(61.4 \%)$ are controlled by public agencies.

The survey responses confirm that public institutions completed more library facility projects than private, nonprofit entities during the study period. However, this finding should be accepted with some caution because the predominance of large, public, multilibrary institutions in the "doctoral/ research" category influences the relative distribution of facility projects across public/private control boundaries.

\section{Carnegie Class}

It was likewise deemed important to determine whether there were any significant differences in facility completion among institutions in different Carnegie classes, regardless of public or private affiliation. The investigators combined similar Carnegie classes (BaccalaureateLiberal Arts with Baccalaureate-General, Master's I with Master's II, etc.) to facilitate statistical analysis. In addition, they created a separate category of "branch or undergraduate library" to reflect possible configuration and usage pattern differences in these libraries. The distribution, by modified Carnegie class, of libraries participating in the survey is shown in figure 2 .

Doctoral and master's institutions comprise 6.6 and 15.5 percent, respectively, of the overall institutional population in the 2000 Carnegie Classification of Institutions of Higher Education. In contrast, baccalaureate and associate degree colleges consti-

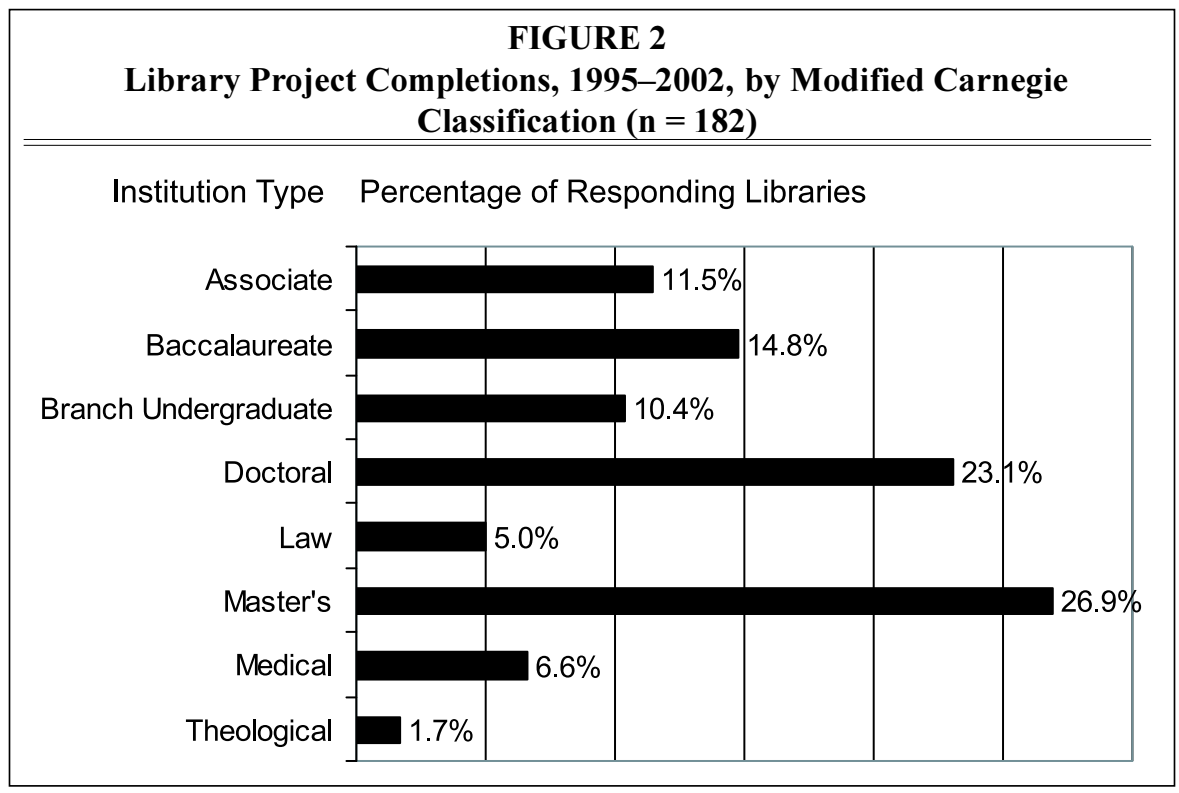




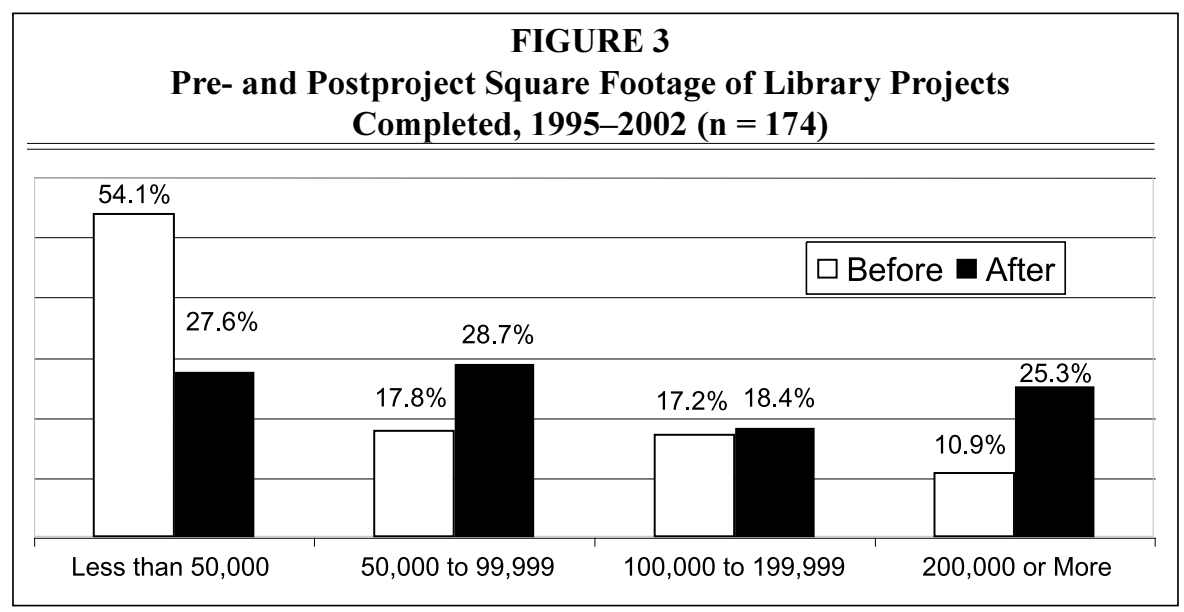

tute 15.4 and 42.3 percent, respectively, of the current Carnegie listing. "Specialized institutions" (theological seminaries, law and medical schools not affiliated with a university, etc.) account for the remaining 19.4 percent of all included institutions. Most branch and undergraduate libraries included in figure 2 are located within a doctorate-granting university, although several private, baccalaureate colleges (Williams, Oberlin) completed significant science branch libraries during the study period.

The frequency distribution data in figure 2 indicate clearly that doctoral institutions enjoyed the greatest success in completing building projects, relative to their number, during the 1995-2002 period. Doctoral institutions accounted for 23.1 percent of all projects completed during the study period while comprising just 6.6 percent of the institutional population. Public master's institutions also completed building projects at a rate higher than their 15.5 percent share among higher education institutions, receiving 26.9 percent of the projects. In comparison, associate institutions were least successful in bringing library-building projects to culmination.

New, expanded, and renovated libraries were built by all type of institutions during the study period. However, it appears that activity was greatest among public, doctoral/research, and master's institutions. Associate institutions were least successful in securing major library facility improvements.

\section{Library Size}

An overall increase in physical size was anticipated for most libraries, except those renovating or reconfiguring an existing facility. Overall size was considered important, particularly because there has been some recent discussion of building steady-state or downsized facilities, assuming that libraries relying increasingly on electronic collections have a diminished need for physical space..$^{57}$ In the case of renovation or reconfiguration projects, the investigators were interested to see what space allocations were made within an existing building footprint.

As figure 3 confirms, there was a significant overall increase in the size of physical library facilities as a result of building projects. Prior to completing their facility projects, 54.1 percent of the responding libraries reported having fewer than 50,000 square feet of space, whereas only 27.6 percent fit into this size category following the project. In contrast, the number of libraries reporting more than 200,000 square feet increased from 10.9 percent before the project to 25.3 percent afterward.

Because respondents were asked to indicate a range ( 25,000 to 49,999 sq. ft., for example) within which their libraries fit, exact space figures were not available to do a more precise study of space changes. 
However, figure 3 indicates a definite pattern of space increases in all size categories of 50,000 square feet or more. Even though the inclusion of renovation/ reconfiguration projects $(12.1 \%$ of total project population in table 1) suppresses the overall tendency toward greater size, it is clear that significant expansion of the physical library was accomplished in most projects completed between 1995 and 2002. Because the number of participating libraries with 200,000 square feet of space increased from 10.9 percent before the project to 25.3 percent afterward, it also is clear that large physical libraries are still being built.

\section{Campus Location}

Location is a pivotal consideration in the success of small business firms. In the academic context, some directors consider oncampus location to be a factor affecting library usage levels. The survey asked respondents to indicate whether their libraries were placed in a central location on campus, a location between the center and the outer edges of the campus, or in a peripheral place. Respondents also were asked to indicate whether their libraries were located within a quarter mile of student parking lots, classroom buildings, residence halls, student centers, and recreation facilities.

Most $(62.1 \%)$ of the responding librarians indicated that their libraries occupied a central location on campus, whereas 18.7 percent reported a neutral location and 19.2 percent a peripheral location. Proximity to a classroom building was reported by 98.9 percent of the responding libraries, indicating that library facilities continue to be located with consideration for the library's academic mission. Proximity to student parking areas $(91.2 \%)$ and student centers (89.0\%) likewise was very high, and most of the responding libraries also were located close to student residence halls (73.6\%) and recreational facilities (73.1\%).

Siting for a new facility can be a major concern on campuses where existing buildings occupy all of the prime locations. Relocation was not an issue for libraries experiencing an addition/renovation, addition, or renovation/reconfiguration project. However, because 43.1 percent of the responding libraries (new, new multipurpose) were placed in a different physical location, it appears that most library buildings are still located in areas frequented by students, even along the periphery of campus. As a result, physical location should not affect facility usage levels at most responding libraries.

\section{Library and Nonlibrary Uses}

Historically, library buildings have been built primarily to accommodate library collections and functions, rather than to provide shared space for the library and other units. The major exception to that tendency has been the location of subjectspecialized branch libraries (music, science, engineering, etc.) in the same building with faculty offices and classrooms supporting those disciplines.

In recent years, however, many academic institutions have combined new or expanded library buildings with space for other campus operations. In addition to seeing how many multipurpose facilities were completed during the study period (table 1), the investigators were interested in seeing the relative proportions of space allocated for library and nonlibrary functions in all projects studied.

Although only twenty-four responding libraries fit into the "new, multipurpose" category, it is apparent from figure 4 that many more academic libraries share at least some of their space with nonlibrary units. The percentage of facilities allocating 100 percent of their space for library purposes declined from 41.6 to 32.9 percent following project completion, suggesting a slight trend away from the stand-alone library concept. However, the number of facilities dedicating 90 to 99 percent of their space for library purposes actually increased from thirty-one (17.9\%) to forty-seven $(27.2 \%)$ in the improved facility. With 79 percent of the participants reporting 75 percent or greater postproject space allocations for library uses and 76 percent indicating similar preproject allocations, there is no clear tendency toward 
greater inclusion of other units in library facilities, contrary to expectations.

It may be more significant that the number of libraries occupying less than 50 percent of available building space declined from 17.3 percent $(n=30)$ preproject to 10.4 percent $(n=18)$ after the project was completed. This finding indicates that fewer libraries are occupying small spaces in buildings primarily built for other purposes. However, the type of nonlibrary facilities sharing building space may be more important for libraries in the long run that the presence of nonlibrary units.

\section{Findings: Technology}

As student ownership of portable computing devices has grown, it has become increasingly important for libraries to provide access to networked resources in general seating areas, as well as through public access workstations. Student ownership of computers has grown sharply over the past five years, and some institutions now are requiring incoming students to acquire a computer. According to a university survey, 96 percent of all full-time Penn State undergraduates owned a computer in fall 2002, laptop ownership was increasing, and 15 percent of the students had a personal digital assistant (PDA) device. ${ }^{58}$
Of the responding libraries, 6.5 percent reported an institutional mandate for student computer ownership. Although personal computers with limited portability still account for the majority of student computer ownership, the declining prices of laptop computers are making them increasingly the machine of choice for students. Given the range of electronic and Internet resources being used by students, libraries need to provide extensive power and network access in public seating areas to permit simultaneous usage of print, electronic, and Internet materials within the physical library.

Copper or fiber-optic telecommunication systems were the preferred choice for wired, end-user network access at the start of the study period. However, recent advances in wireless systems have made it important to examine the use of both network access solutions in academic libraries. This section examines a wide range of technology solutions-premises wiring systems, data ports, wireless systems, public access workstations, and instruction labs-implemented in library facility projects between 1995 and 2002.

\section{Premises Wiring Systems}

To accommodate mobile computing/network access needs, academic libraries need both an extensive, high-quality telecom-

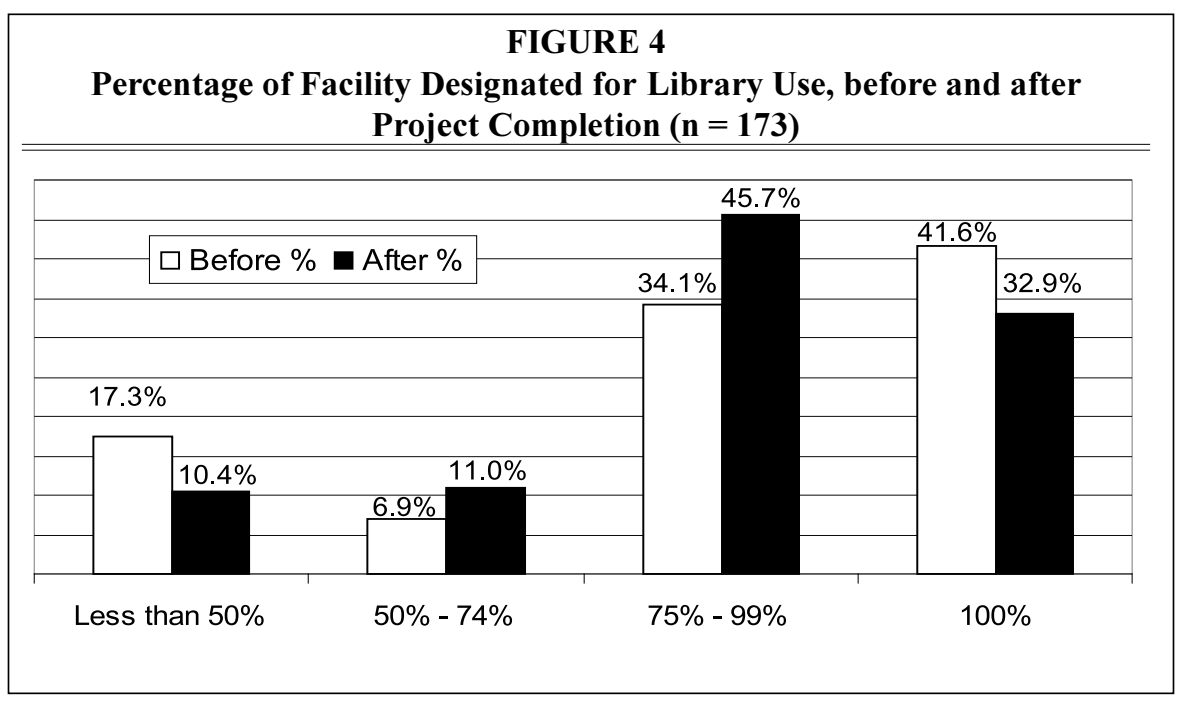


TABLE 2

Premises Wiring Systems Used Before and After Project Completion $(\mathbf{N}=\mathbf{1 7 1})$

\begin{tabular}{lcccc} 
Wiring Type & $\begin{array}{c}\text { Preproject } \\
\text { Uses }\end{array}$ & $\begin{array}{c}\text { Postproject } \\
\text { Uses }\end{array}$ & $\begin{array}{c}\text { Preproject } \\
\text { Percentage }\end{array}$ & $\begin{array}{c}\text { Postproject } \\
\text { Percentage }\end{array}$ \\
\hline CAT 2 & 120 & 28 & $70.2 \%$ & $16.4 \%$ \\
CAT 5 & 37 & 62 & $21.6 \%$ & $36.3 \%$ \\
CAT 5-E & 5 & 20 & $2.9 \%$ & $11.7 \%$ \\
Premium CAT 5 & 4 & 12 & $2.4 \%$ & $7.0 \%$ \\
CAT 6 & 0 & 13 & $0.0 \%$ & $7.6 \%$ \\
Fiber Optic & 5 & 36 & $2.9 \%$ & $21.0 \%$ \\
\hline Total & $\mathbf{1 7 1}$ & $\mathbf{1 7 1}$ & $\mathbf{1 0 0 \%}$ & $\mathbf{1 0 0 \%}$
\end{tabular}

munications infrastructure and widespread data connectivity in public seating areas. Table 2 shows the type of premises wiring (i.e., wiring to the desktop or wall jack, not data lines connecting library data closets to the campus network) used before and after project completion.

Table 2 confirms that major telecommunications upgrades were accomplished in most of the projects examined. More than 83.6 percent of the libraries responding to this question now have, at minimum, unshielded twisted pair (UTP) category 5 (CAT-5) copper wiring throughout the building. This type of wiring infrastructure provides sufficient bandwidth to accommodate downloads of large textual, graphic, and data files. More than one-third of the responding libraries utilized basic CAT- 5 as their postproject wiring solution.

Smaller percentages of libraries used more advances versions of CAT 5 (5-E, premium CAT-5) and CAT-6 copper wiring systems for providing network access throughout the facility. Somewhat surprisingly, 16.4 percent indicated that they are still using UTP CAT-2, a far less robust solution with a bandwidth considerably smaller than that in CAT-5 wiring. It is possible that the number of CAT-2 installations was exaggerated slightly by survey respondents because CAT-2 wiring was the default answer registered for libraries skipping this question. However, it appears that approximately one-fifth of the participating libraries did not implement major infrastructure upgrades.
At the opposite end of the bandwidth spectrum, 21.0 percent of the responding libraries indicated that they deliver fiberoptic cable connections directly to the desktop. Although it is possible that some respondents confused fiber-optic connections to data closets with premises wiring, follow-up site visits have confirmed the presence of "fiber to the desktop" in many enhanced library buildings. Although the investigators are not entirely confident that building-wide fiber installation has exceeded the 20 percent level in these projects, the data clearly confirm that fiber-optic wiring has been utilized in many new and improved academic libraries.

Even allowing for some respondent errors, it is clear that 80 percent or more of the participating libraries now provide CAT5, CAT-6, or fiber-optic data connections for end users. These libraries are well positioned to accommodate growing student use of laptop computers and other mobile devices.

\section{Wired Network Connections}

A high-quality telecommunications infrastructure is a prerequisite for effective delivery of data to end users. However, an extensive system of data ports (a.k.a., docking stations) or wireless transceivers is needed in public seating areas to permit effective, facilitywide use of mobile computing devices.

Figure 5 documents a dramatic, postproject increase in the availability of wired network connections. Of the responding libraries, 62.2 percent had fewer 
than fifty network connections before project completion. Because the data port figures also include staff, public access computer, and instruction lab connections, the preproject figures actually overstate the availability of network connections for end users. Clearly, most responding libraries were poorly equipped to address mobile computing needs prior to project initiation.

Following project completion, 51.7 percent of all responding libraries reported having 250 or more data ports. Only 7.6 percent of the participants had had this many data ports before improving their telecommunication infrastructures. Although the inclusion of office and public access computer ports may slightly exaggerate the direct impact on mobile end users, it clear that many postproject data ports were allocated for plug-in use. In contrast, it is surprising that 14.0 percent of the responding libraries did not report having more than fifty data ports following project completion. On balance, postproject connectivity advances are quite significant for student users, who are finding network ports already present in many enhanced library facilities as they acquire mobile computing devices.

\section{Wireless Systems}

Wired systems have been the dominant option for providing end-user network access through most of the 1995-2002 study period. More recently, sharp improvements in wireless systems and some user preferences for "untethered" solutions have made them a viable, lower-cost alternative for providing end-user network access. The wireless option has been especially attractive for facilities undergoing renovation, where the installation of wired data channels would be disruptive and costly.

Wireless systems were rare in academic libraries before project completion, with 87.1 percent of the responding libraries lacking any wireless installation. In contrast, 57.9 percent of the participating libraries reported that wireless connectivity was available in their facility, to at least some degree, by early 2003. In many cases, wireless systems were installed well after the building project was completed to complement an existing wired infrastructure. However, the data indicate that wireless systems are now commonplace in libraries undergoing a building improvement project since 1994.

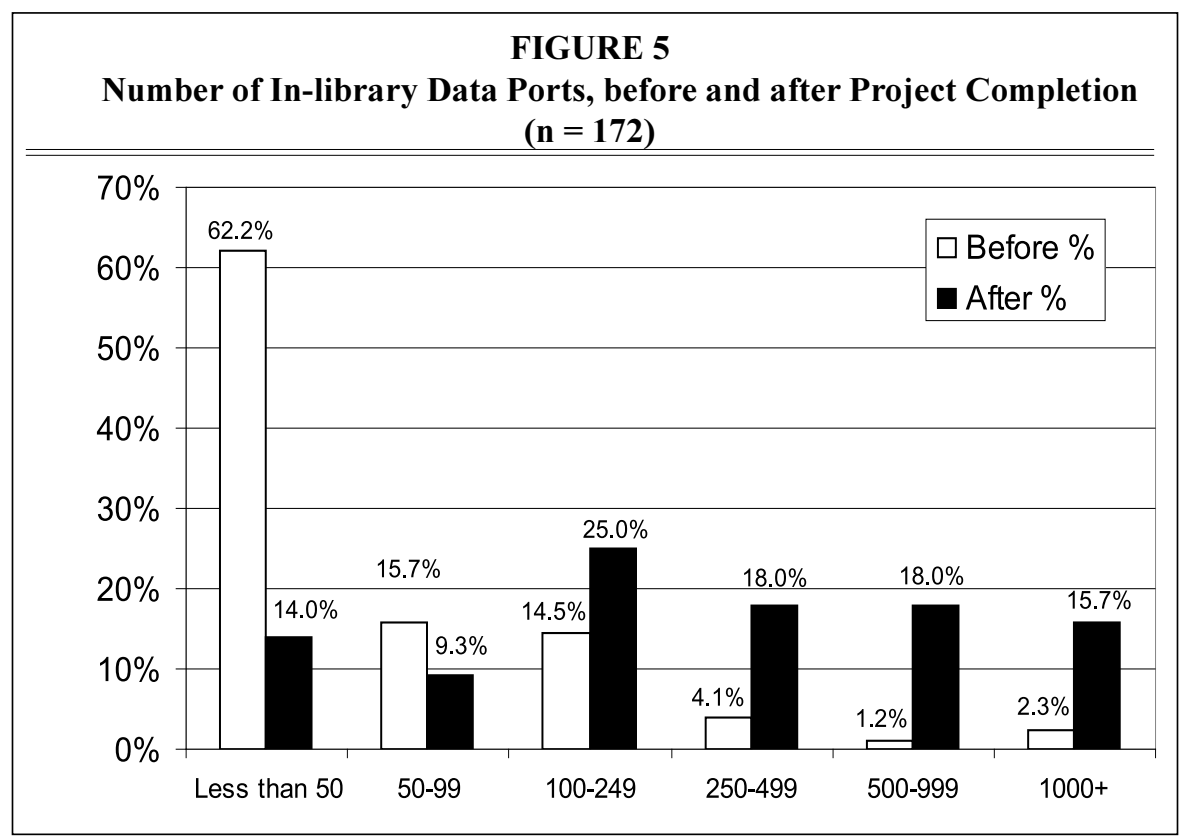




\section{Public Access Workstations}

Although student ownership of computers has increased rapidly, the majority of student-owned computers are still not portable. The library also has an obligation to provide equitable, on-site access for electronic and Internet resources. Some libraries have recently installed applications software on public workstations to help students manipulate search results, retrieve e-mail, and write papers without changing locations. Figure 6 compares the number of public access workstations provided in responding libraries before and after project completion.

As figure 6 confirms, most enhanced libraries have expanded their number of public access workstations significantly. Prior to project completion, 49.1 percent of the responding libraries had fewer than ten public access workstations. After project completion, only 15.8 percent of these libraries still had fewer than ten public computers and just 32.2 percent had fewer than twenty such workstations.

In comparison, 68 percent of the postproject libraries had more than twenty public access computers, 41 per- cent had more than sixty public workstations, and 24.6 percent had more than one hundred such devices. Because only 12.1 percent of the responding libraries had as many as sixty public computers in the preproject library, it is clear that expanding the number of public workstations was a frequent project priority. Although the survey did not address the inclusion of applications software in library computers, many libraries have done so, thereby increasing the potential use and functionality of these machines.

During postsurvey site visits to responding libraries, it was discovered that a low number of public access computers might not reflect a lack of provision for student access to electronic and Internet resources. The Howard University Law Library loans laptop computers to law students, instead of providing a conventional cluster of public workstations. Eight public workstations are provided for community users. Although "loaner laptops" are becoming a commonplace service of academic libraries, Howard Law's substitution of loaner machines for a fixed workstation cluster may presage a coming trend.

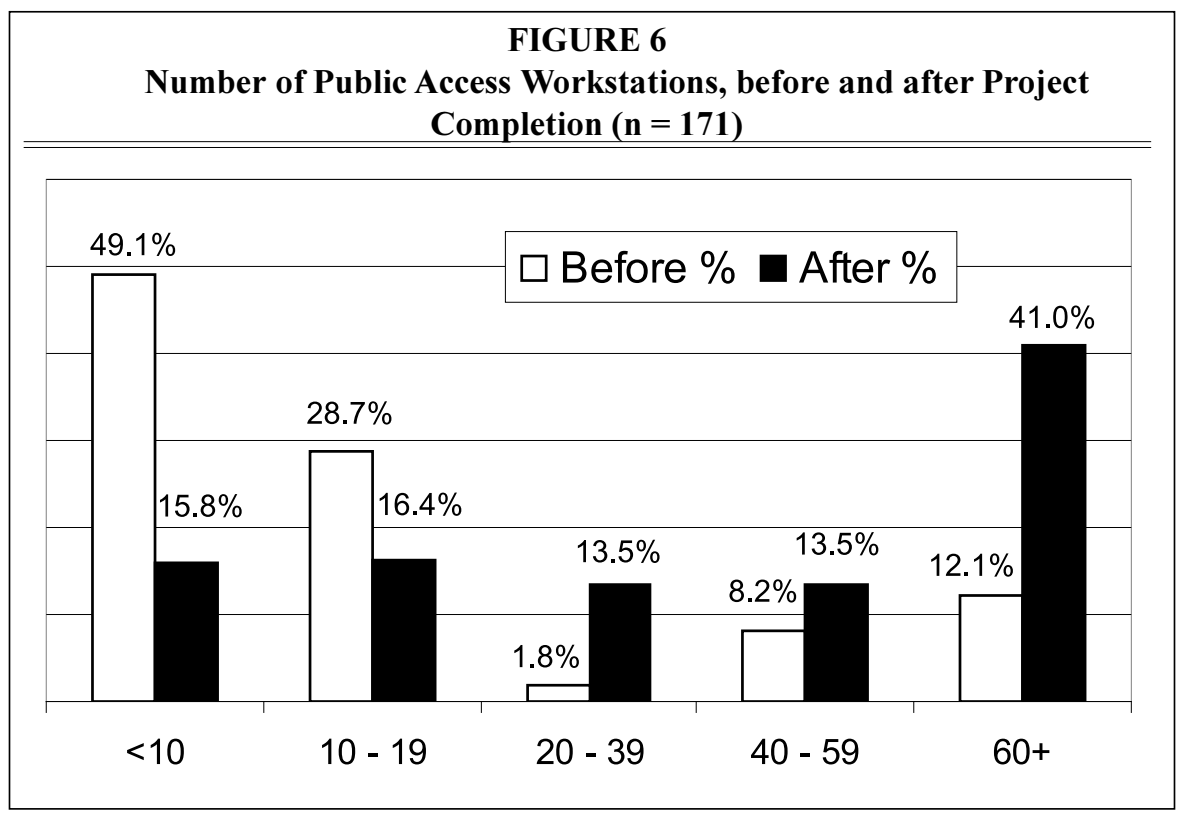




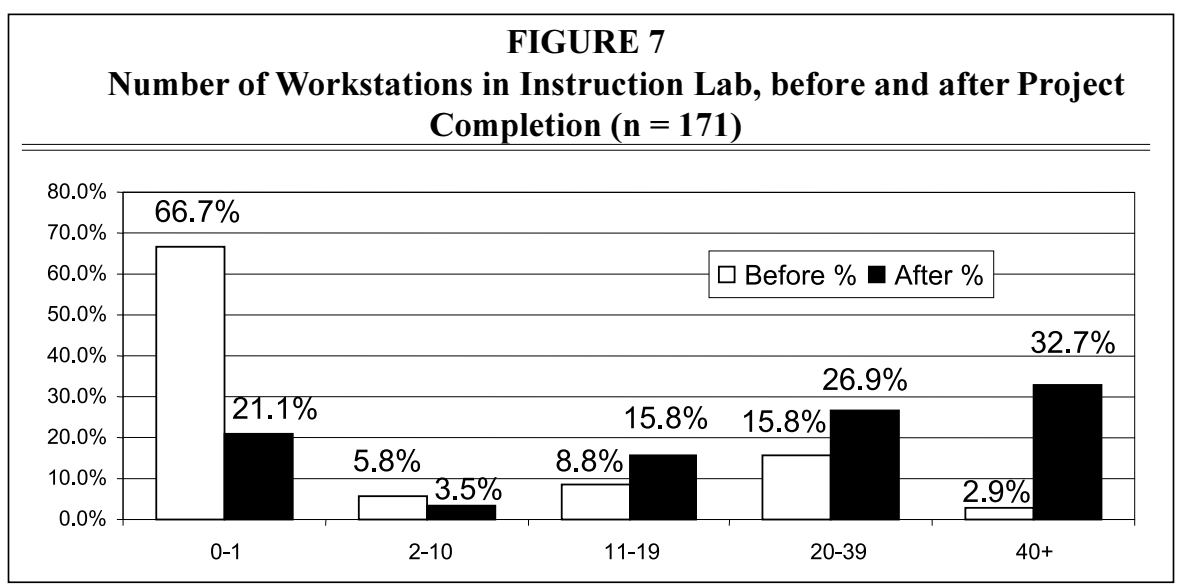

\section{Library Instruction Facilities}

Information literacy instruction is a major focus of library services today. Most respondents identified inadequate (or nonexistent) instruction facilities as a major shortcoming of the preproject library. The number of workstations in a dedicated library instruction lab or electronic classroom has a significant effect on the type of instruction provided. Where more individual workstations are available, students are able to participate more actively in library instruction sessions, thereby increasing their knowledge of-and comfort level with-a wide range of electronic resources. Those comfort and knowledge levels should, it was assumed, result in more sophisticated use of library resources and more frequent use of the postproject library facility. Figure 7 provides before-and-after comparisons of the number of workstations available in library instruction labs or dedicated eclassrooms.

Prior to project completion, 66.7 percent of the participating libraries either lacked a dedicated instruction lab altogether or had a facility with only one instructor workstation. These libraries had a severely limited capacity to provide an active learning experience for students in the library instruction context.

After completion, 75.4 percent of the responding libraries had at least eleven workstations in their instruction labs, and 59.6 percent had more than twenty com- puters. In comparison, only 15.2 percent lacked an instruction lab and just 5.8 percent had an instructional facility with only one workstation. The improvements in instruction lab facilities are among the most dramatic findings revealed by this survey. Instruction lab enhancement was clearly a major objective for librarians in project planning. The vast majority of libraries secured a teaching facility conducive to in-depth student training in the critical use of catalogs, print resources, electronic databases, and Internet sites.

\section{Findings: User Space}

Many academic libraries have cannibalized existing seating areas to accommodate collection growth. Although this measure has been justified to maintain and preserve print and nonprint collections in the absence of other alternatives, it has affected library use by reducing the number of seats available for research and study.

The investigators were interested to know whether libraries had identified seating expansion - and the type of seating provided-as a priority for facility improvement. If seating were not expanded, it could be inferred that planners considered the library's current seating capacity adequate or gave greater weight to other facility needs. If wired and/or wireless network access was provided at a significant number of seats, the need for both traditional and technology-enhanced learning stations 
FIGURE 8

General Use Seats in Library, before and after Project Completion $(n=171)$

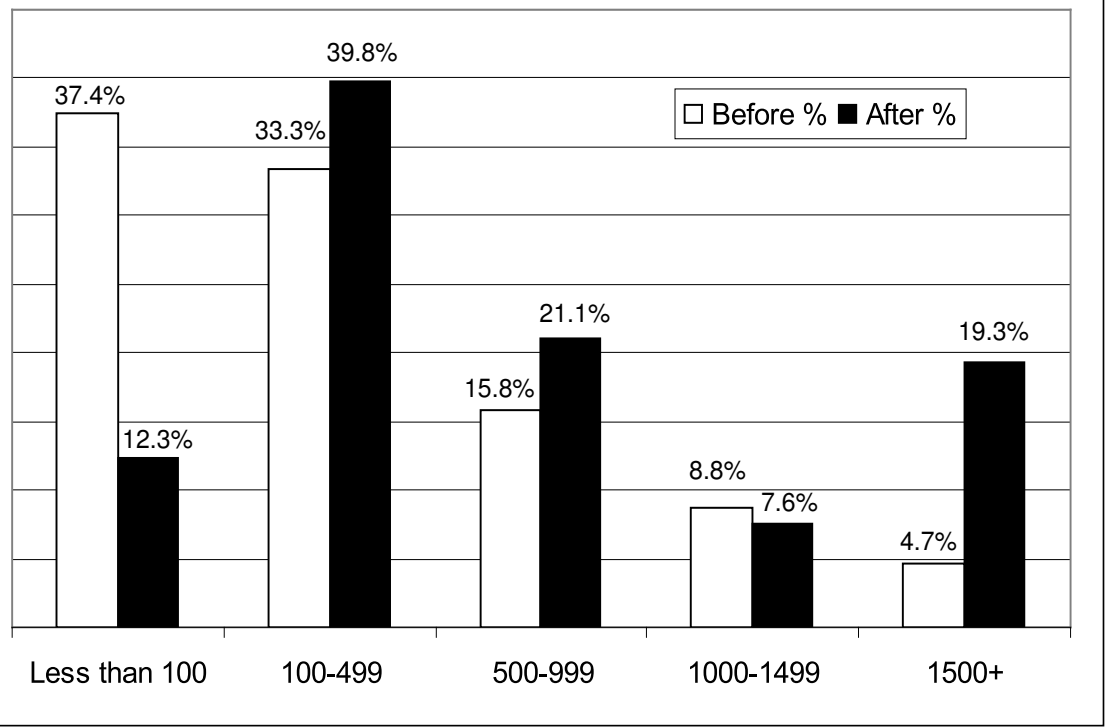

had been envisioned. If the number of group study rooms was increased significantly, planners had anticipated the growing need for collaborative learning spaces.

\section{Overall User Seating}

It was anticipated that most projects would expand the amount of general use (table, carrel, lounge) seats. The data in figure 8 confirm this expectation.

Smaller libraries benefited most dramatically from seating increases. The percentage of libraries having fewer than one hundred seats declined from 37.4 percent before the project to 12.3 percent afterward. At the other end of the spectrum, the number of libraries with 1,500 or more seats increased from eight to thirty-three facilities. Clearly, general seating expansion was a priority for most projects. No respondents reported a reduction in the amount of public seating after project completion.

The consistent expansion of on-site seating capacity is an important finding because it reflects planner expectations that users will continue to come to the physical library. Assumptions about future library facility use underlie the types of seating provided.

\section{Group Study Seating}

Group study rooms generally are recognized as an essential component of successful library design today, given the emphasis on collaborative learning in recent years. Because 45.6 percent of the responding libraries did not have a single group study room before project implementation and 80.7 percent had five or fewer such rooms, most of the responding libraries had an acute need to increase their group study capacity. Figure 9 compares the number of group study rooms available in the pre- and postproject libraries.

The post-project increase in group study capacity was significant, but not as dramatic as might have been expected. Following improvements, 44.5 percent of the responding libraries had eleven or more group study rooms, whereas 8.2 percent still did not provide any group studies and another 19.9 percent had just one to five studies. Fifty-four percent of the responding libraries clustered in the six to ten or eleven to nineteen study room range. Only eight percent of the responding libraries provided more than thirty group study rooms, even though some of them serve large student populations. 
Although these libraries clearly expanded their group study capacities, most did not increase it on a scale sufficient to fully address current and future demand. The University of Georgia's Student Learning Center, with ninety-six dedicated group study rooms, was a major exception to this tendency toward incremental increases. Postsurvey site visits have confirmed that demand for group study spaces often exceeds library capacity. A parallel demand for enclosed, single-user rooms also was noted in the site visits.

\section{Wired Seating}

Even though figure 5 indicated the actual number of data ports in a library facility, that figure does not necessarily reflect the extent of network connectivity options available for mobile computer users. Many of those data ports are allocated for fixed functions, such as public access computers, instruction labs, and staff offices. Advances in providing wired network access for end users are depicted in figure 10, which shows the percentage of wired user seats in the library before and after the project.

The advances in wired seating are among the most dramatic findings of this study. Of the responding libraries, 73.7 percent lacked any wired public seating before undertaking their improvement projects. These libraries were simply not equipped to any direct network access for laptop computer users. Since project completion, 46.8 percent of the responding libraries now offer wired network access from at least half of their seats, with 12.3 percent providing data access from every seat in the facility.

The survey also confirmed that 14.6 percent of the improved libraries did not provide wired network access at any user seats. There are two explanations for this finding. First, many projects completed since 2000 have relied exclusively on wireless systems to provide network access at the desktop. Wireless systems have been especially attractive for renovation and addition/renovation projects in older buildings, where installation of wired systems would be expensive, time-consuming, and disruptive to library services. Second, a few projects completed early in the 1995-2002 study period apparently did not anticipate the need for decentralized network access.

Clearly, wired, end-user network access has been an objective in most recent library facility projects. Although physical and financial constraints have often precluded building-wide, wired access, a significant investment has been made. As a result, mobile computing device users can find wired network connections at more than 85 percent of the facilities completed since 1994. This capability is a major advance, enabling users to conduct research, write, and study from many or all library seating locations using both print and online resources.

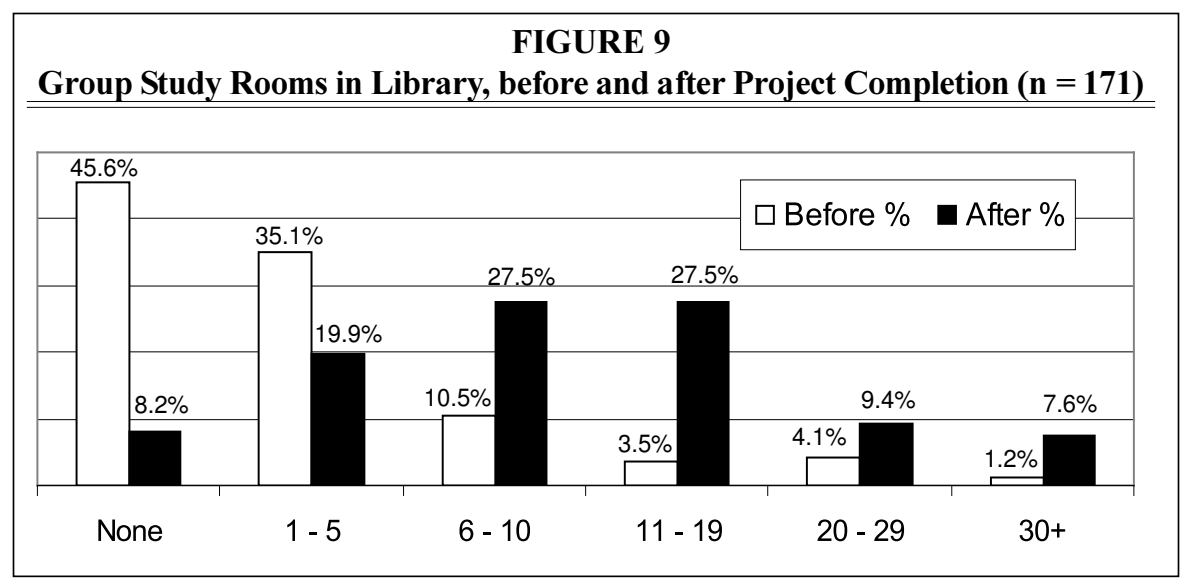


FIGURE 10

Wired User Seating in Library, before and after Project Completion $(n=171)$

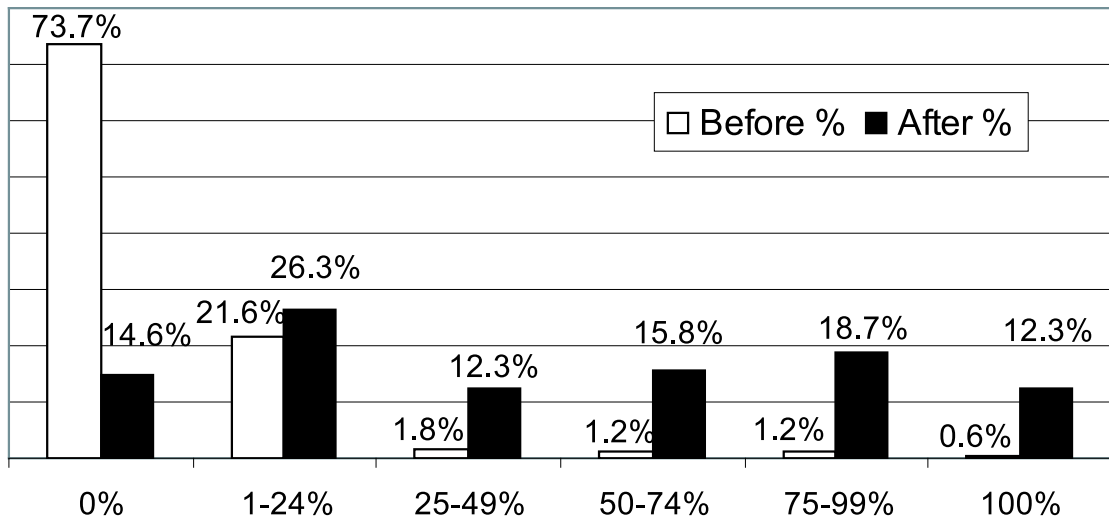

\section{Wireless Seating}

As noted in table 3, 93.0 percent of the responding libraries lacked any wireless installation prior to finishing their building projects. In contrast, 24.6 percent of the responding libraries offered wireless coverage at 100 percent of all public use seats following project completion.

The percentage of libraries delivering wireless network access at all seating locations was approximately twice that of libraries providing wired access at 100 percent of all public seats. (See figure 10.) However, when libraries supplying facilitywide wireless access are excluded, the breadth of wireless coverage access declines sharply. Although 34.6 percent of the postproject libraries offered wireless access at one-half of their seats, 46.8 percent delivered wired network access at one-half of all seating locations (figure 10).

The relatively lower usage of wireless systems partially reflects their inferior carrying capacity during earlier years of the study period. Given their lower cost, improved quality, and popularity with consumers, it is likely that wireless systems will be utilized increasingly in all types of future library projects. Many wired libraries are now installing wireless systems to complement their existing wired infrastructure. This hybrid solution is likely to become increasingly

\begin{tabular}{|lcccc|}
\hline \multicolumn{5}{|c|}{ TABLE 3 } \\
Seats with Wireless Network Access, before and after Project \\
Completion (n= 171)
\end{tabular}


popular in the future, although wireless systems present security problems and still cannot match the bandwidth capacity of fiber-optic systems.

\section{Findings: Collection Provisions}

The exhaustion of shelf space for print collections is a visible, readily understood reason justifying library facility expansion. When books cannot be reshelved, students and faculty members complain and higher education administrators understand that a space crisis has developed.

However, collection space planning is not as simple and straightforward as it was just ten to fifteen years ago, given expanding library investments in electronic databases and the growth of digital libraries. As libraries provide access to collections in multiple formats, the balancing of user, technology, collection, and staff needs has become more complicated.$^{59}$ Libraries need to include accurate projections of future collection growth patterns in facility plans despite long-term uncertainties about collection evolution.

Survey participants were asked to indicate the provisions their libraries have made for print collection growth during project planning. The investigators focused on three facets of print collection planning: long-range stack capacity, use of compact storage, and reliance on off-site storage facilities. It was felt that these questions would indicate the nature and quality of planning for collection expansion.

\section{Print Growth Capacity}

Many libraries have cancelled print journal subscriptions aggressively because the same or comparable titles have become available online through aggregator databases. ${ }^{60}$ Others have redirected monographic acquisitions funding to acquire a broad array of electronic resources. Older (microform) and more recent (DVD) technologies place additional space, equipment, and fiscal pressures on academic library budgets.

The investigators were specifically interested in knowing how extensively project planners had allowed for print collection growth. It was believed that collection space allocations would reflect four factors: (1) projected future importance of print collections for library users; (2) accuracy of space requirement projections; (3) availability of project funding to address long-range collection needs; and (4) relative importance of onsite collection storage among competing space priorities.

To ascertain how effectively facility planners had addressed long-range collection needs, the investigators asked respondents to indicate a projected date of shelf space exhaustion for print collections at current acquisition rates. These projections incorporate shelf space in both conventional and compact shelving. The responses to this question are summarized in figure 11 .

It is impossible to determine the exact mix of factors influencing collection space decisions without follow-up interviews or surveys. However, the findings in figure 11 indicate that more than one-third of the responding libraries will exhaust their existing shelf space by 2010. Many of these libraries already are experiencing an acute shelf space crisis; others are rapidly depleting available shelf space. Another 17.3 percent of the responding libraries will exhaust their shelf space by 2015, giving them some time to plan storage alternatives or start mobilizing support for another facility project.

In contrast, 29 percent of the libraries built at least twenty years of collection growth capacity into their facility improvement plan. Having sufficient stack space to accommodate collection growth in the near term, these libraries should be able to manage and preserve their print collections effectively, with minimal shifting in the near future.

Those libraries with twenty or more years of shelf space capacity are well positioned to manage their print collections and provide ready access to them in the foreseeable future without impacting other library operations or user seating. Those postproject libraries without adequate stack capacity are facing some 


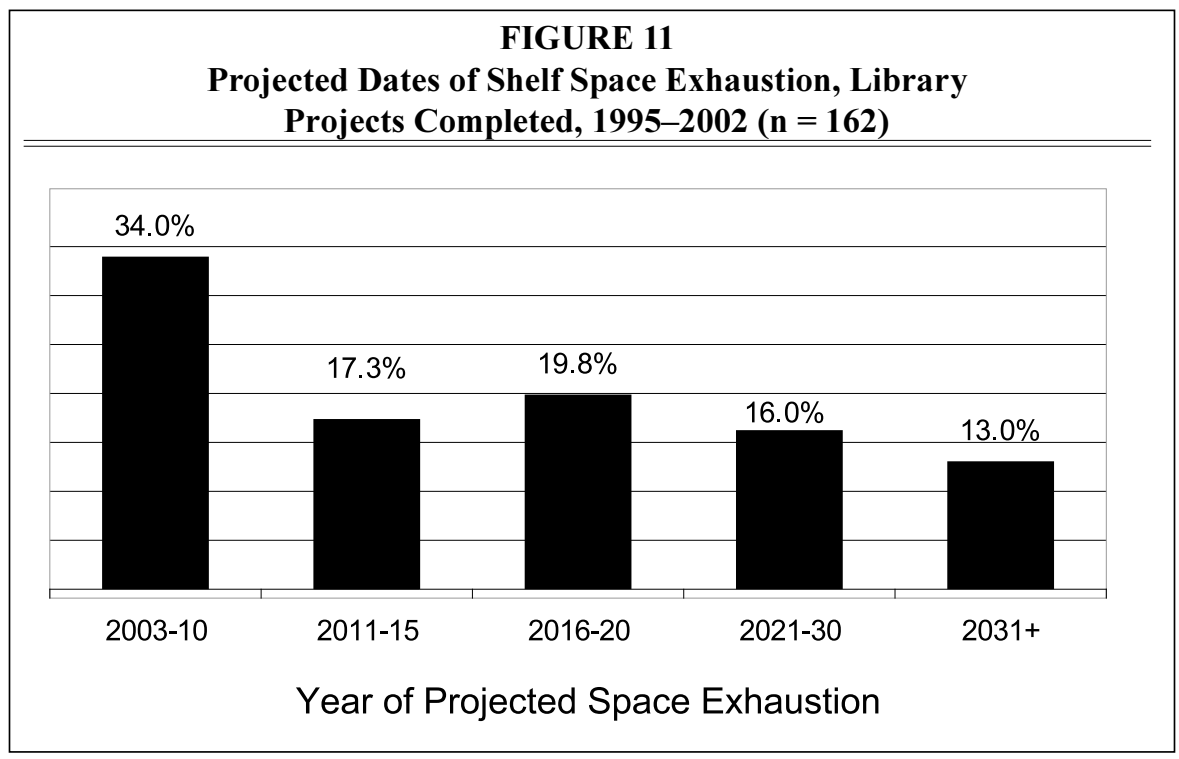

hard decisions. It is difficult and embarrassing to argue that additional collection space is needed less than ten years after the completion of a building project. Given the many claims for limited institutional funding, directors in those libraries will need to weed collections extensively, explore off-site storage options, retrofit some stack areas for compact shelving, or cannibalize other areas to accommodate collection growth.

\section{Compact Shelving Use}

Compact shelving has emerged as a viable and effective means for storing a large number of print or nonprint items in limited space, given a floor loading capacity sufficient to support added weight. Although it traditionally has been viewed as a high-density storage option for low-use materials, compact shelving has been employed in many new libraries to stretch their storage capacity and capture space for user seating, service points, and other needs.

The University of Kentucky stores more than 90 percent of its primary print collection on compact storage in its new main facility, the William T. Young Library. Nova Southeastern University has intermixed compact shelving and user seating areas effectively to provide ready access to collections and nearby seating. This humanizing approach also minimizes the industrial, warehouse ambience found in some compact storage installations.

Many libraries have utilized compact shelving as a preferred alternative to offsite storage facilities and / or overcrowded traditional shelf space. Although lacking the instant browsability of traditional shelving units, high-quality compact shelving systems are reasonably intuitive and can be used readily by most students and faculty members. Compact shelving systems permit libraries to bring entire collections together under one roof, when space is not available for doing so without impacting user seating space or other functions. Table 4 shows the extent of compact storage use in the libraries surveyed.

Slightly more than one-half of the responding libraries made some use of compact shelving, but only 12 percent used it for one-quarter or more of their collections. Compact shelving is used in various libraries to store older periodical volumes, archival materials, reserve readings, vinyl records, compact disks, and other media. In some libraries, it is an integral part of the monographic storage system. 
Although 47.3 percent of the responding libraries did not include any compact shelving in their facility plans, compact shelving is increasingly accepted as a mainstream option for "stretching" the physical facility's storage capability and limiting the overall percentage of space devoted to collection storage. Although some extra user effort is required to retrieve materials, the compact storage option expands collection access within a finite space, does not infringe on other library needs, and appears to be generally accepted by users. It has become a strategic choice for maximizing the use of space within facilities, and its growing use in new buildings for core monographic collections, not just archival or low-use materials, is significant.

\section{Off-site Storage Use}

From the standpoint of user access, off-site storage is the least desirable of the major options for addressing shelf space limitations within the physical library. Most obviously, patrons do not have immediate access to items stored off-site. Where lowuse items have been selected carefully for relocation to a remote location, the impact on most users can be minimal. However, the library and/or the institution does incur additional staffing and utility costs for maintaining such a facility. Usage of offsite storage facilities by survey participants is described in table 5 .
TABLE 4

Libraries Using Compact Shelving in Postproject Facility $(n=165)$

\begin{tabular}{lcc}
$\begin{array}{l}\text { Percentage of Collection } \\
\text { in Compact Storage }\end{array}$ & $\begin{array}{c}\text { Number of } \\
\text { Responses }\end{array}$ & $\begin{array}{c}\text { Percent of } \\
\text { Responses }\end{array}$ \\
\hline None & 78 & $47.3 \%$ \\
$<10 \%$ & 38 & $23.0 \%$ \\
$10-24 \%$ & 29 & $17.6 \%$ \\
$25-49 \%$ & 8 & $4.8 \%$ \\
$50-74 \%$ & 7 & $4.2 \%$ \\
$75-99 \%$ & 4 & $2.4 \%$ \\
$100 \%$ & 1 & $0.6 \%$ \\
\hline Total & 165 & $\mathbf{9 9 . 9 \%}$
\end{tabular}

*Note: Percentages do not equal $100.0 \%$ due to rounding.

\begin{tabular}{|c|c|c|}
\hline \multicolumn{3}{|c|}{$\begin{array}{c}\text { TABLE } 5 \\
\begin{array}{l}\text { Off-Site Storage Use in Postproject } \\
\text { Libraries }(n=165)\end{array} \\
\end{array}$} \\
\hline $\begin{array}{l}\text { Percentage of Collection } \\
\text { Stored Off-site }\end{array}$ & $\begin{array}{l}\text { Number of } \\
\text { Responses }\end{array}$ & Percentage \\
\hline None & 120 & $72.7 \%$ \\
\hline$<10 \%$ & 20 & $12.1 \%$ \\
\hline $10-24 \%$ & 14 & $8.5 \%$ \\
\hline $25-49 \%$ & 9 & $5.5 \%$ \\
\hline $50 \%$ or more & 2 & $1.2 \%$ \\
\hline Total & 165 & $100.0 \%$ \\
\hline
\end{tabular}

Most (72.7\%) of the libraries completing a facility project between 1995 and 2002 were able to avoid dependence on an offsite storage location. However, 15.2 percent of the responding libraries did rely on a remote site to store one-quarter or more of their print collection materials, whereas a small percentage $(1.2 \%)$ of the postproject libraries had one-half or more of their collections stored in another location.

Off-site storage solutions are preferable to the reduction of user seating or other cutbacks in facility features. In some cases, offsite storage may be a conscious choice utilized to maximize the enhancement of other functions in a new or expanded building.

In renovated buildings, it may be needed increasingly as other spaces are improved. In the long run, however, materials stored off-site are not immediately accessible to patrons. Moreover, they create offsite storage maintenance and retrieval costs. Off-site storage may be necessary in many cases, but it also may reflect a project's failure to bring entire library collections under one roof for convenient user access.

\section{Automated Storage and Retrieval Systems}

Although the survey did not specifically ask whether libraries were using automated stor- 
age and retrieval (ASAR) systems, both the University of Nevada-Las Vegas and California State University-Northridge reported that they are doing so. The UNLV installation provides a planned, long-term collection expansion capacity within the physical confines of a major new facility opened in 2001. The ASAR system is clearly visible from the main atrium area in the UNLV library, so it is a viable, onsite solution to a collection space issue. The Cal State-Northridge system was installed as part of a reconstruction and retrofitting project following a major earthquake. ${ }^{61}$

\section{Findings: Interior Features}

Although they are not the major focal points of this study, several environmental factors also may contribute to facility use by creating a comfortable, pleasing setting. The authors asked respondents to indicate what floor coverings, floor colors, and wall colors were used in both the preproject library and the current facility. In addition, they were asked about the presence of artwork in public areas in both the old and current libraries.

The findings in this section are indicators of current trends in library interior design. They also may be factors subtly encouraging people to use or avoid particular library facilities.

\section{Floor Cover}

One of the more dramatic changes found in the study was the shift from harder (tile, wood) floor surfaces to softer, carpet coverings. Of the responding libraries, 35.6 percent had hard floor surfaces in the preproject library, but 86.5 percent of them installed a carpeted (or predominantly carpeted) surface in the postproject library.

Although the trend toward carpeted surfaces is unmistakable, it is not an entirely unmixed blessing. Carpeted surfaces are easier on staff and user legs, and provide some noise absorption, but are more difficult to maintain and may harbor disease-bearing microbes. However, softer carpeted surfaces are the clearly the preferred choice of architects and librarians today.

\section{Floor Color}

The choice of floor color has both architectural and behavioral implications for academic library facilities. As table 6 illustrates, many institutions moved in a different visual direction when planning library facility improvements.

The significant increases in blue and green floors are indicative of a growing preference for soft, "cool," timeless colors in a learning environment. In contrast, orange and yellow have clearly fallen from favor as dated, 1970s colors. Brown earth tones have also diminished in popularity, although not as dramatically as orange and yellow. Beige, gray, and multicolored coverings have remained popular choices, with the latter also appealing to many institutions for its concealment of dirt. Somewhat surprisingly, given the overall tendency away from bright, "hot" colors, red floorings have increased in popularity.

\section{Wall Color}

Before-and-after changes in wall color selection were minimal, in contrast with the floor color findings. Of the responding libraries, 46.3 percent reported having white walls after the project, compared with 45.2 percent in the preproject library. The percentage selecting beige as their wall color increased from 24.8 to 32.5 percent. Multicolored and gray walls were reported for 6.3 percent of the responding libraries. No other color accounted for more than 2.5 percent of the postproject wall colors.

Well-selected color schemes can create architecturally interesting spaces without detracting from the research and study environment. The University of Maryland Health Sciences \& Human Services Library has eight wall colors, including a dramatic, two-story, red wall opposite the circulation counter in its entrance atrium. Cooler colors are used in patron seating areas. However, this facility is an exception from the general tendency to use one or two nondistracting colors on wall surfaces.

Whereas floor color selections changed significantly, the postproject distribution of wall color choices was remarkably 


\begin{tabular}{|c|c|c|c|c|c|}
\hline \multirow{4}{*}{$\begin{array}{l}\text { similar to the } \\
\text { preproject distri- } \\
\text { bution. Clearly, } \\
\text { there is an ongo- } \\
\text { ing preference } \\
\text { for neutral col- } \\
\text { oration in library } \\
\text { interior walls. }\end{array}$} & \multicolumn{5}{|c|}{$\begin{array}{c}\text { TABLE } 6 \\
\text { Primary Library Floor Colors, before and } \\
\text { after Project Completion } \\
\end{array}$} \\
\hline & Color & $\begin{array}{c}\text { Preproject } \\
\text { Number }\end{array}$ & $\begin{array}{c}\text { Postproject } \\
\text { Number }\end{array}$ & $\begin{array}{l}\text { Preproject } \\
\text { Percentage }\end{array}$ & $\begin{array}{l}\text { Postproject } \\
\text { Percentage }\end{array}$ \\
\hline & Beige & 23 & 23 & 15.2 & 14.1 \\
\hline & Blue & 19 & 37 & 12.6 & 22.7 \\
\hline \multirow{12}{*}{$\begin{array}{l}\text { Artwork } \\
\text { The presence of } \\
\text { artwork in the li- } \\
\text { brary facility is a } \\
\text { potentially wel- } \\
\text { coming feature. } \\
\text { Because } 68.4 \text { per- } \\
\text { cent of the } \\
\text { preproject librar- } \\
\text { ies already dis- } \\
\text { played artwork } \\
\text { on their walls, the }\end{array}$} & Brown & 21 & 12 & 13.9 & 7.4 \\
\hline & Gold & 3 & 0 & 2.0 & 0.0 \\
\hline & Gray & 25 & 27 & 16.6 & 16.6 \\
\hline & Green & 16 & 28 & 10.6 & 17.2 \\
\hline & Multi-Colored & 20 & 23 & 13.2 & 14.1 \\
\hline & Orange & 12 & 0 & 7.9 & 0.0 \\
\hline & Purple & 0 & 3 & 0.0 & 1.8 \\
\hline & Red & 4 & 9 & 2.6 & 5.5 \\
\hline & White & 3 & 1 & 2.0 & 0.6 \\
\hline & Yellow & 5 & 0 & 3.3 & 0.0 \\
\hline & Total & 151 & 163 & 99.9 & 100.0 \\
\hline & \multicolumn{5}{|c|}{ *Note: Percentages do not equal $100.0 \%$ due to rounding. } \\
\hline
\end{tabular}

work in 81.9 per-

cent of the postproject libraries was not a major departure from preproject ambience features. It appears that the use of artwork to improve the library environment has long been part of academic libraries' decorative agenda and continues to be so.

\section{Findings: Nonlibrary Facilities}

As noted in table 1, new, separate, standalone libraries comprise less than 30 percent of the survey population. Multipurpose facilities are becoming increasingly popular as a means for institutional cost containment, and they may create strategic partnerships benefiting both library and the nonlibrary organizations. ${ }^{62}$ In other instances, inclusion of the library in a multipurpose facility may be the only politically viable strategy for securing institutional commitment toward a major facility enhancement.

However, even libraries defined by their directors as stand-alone facilities often include nonlibrary components within the building. A comparison of figures 12 and 13 confirms the increasing presence of nonlibrary facilities in postproject libraries.

Nonlibrary facilities were hardly unusual in the preproject libraries, with con- ference rooms and general computer labs found most commonly. However, closer inspection of figures 12 and 13 reveals two major trends. First, the presence of every type of nonlibrary facility listed above not only increased but also doubled or nearly doubled in postproject libraries. Second, the percentage of libraries providing food and drink service (cafe or snack bar) more than quadrupled.

Although they are found increasingly in library facilities, snack bars and cyber cafes are still a controversial issue for some academic librarians. Its supporters perceive the inclusion of a food and drink service as a step toward providing a welcoming environment for sustained use. They note that major bookstores have created a more congenial environment by providing coffee and solid refreshments. Its detractors view the snack bar or cyber cafe as a threat toward preservation of library materials and the maintenance of a reasonably quiet atmosphere.

The growing presence of nonlibrary facilities within the library shell is not surprising. The investigators expected to find significant increases in the presence of snack bars, computer labs, and multimedia production centers. However, the pres- 


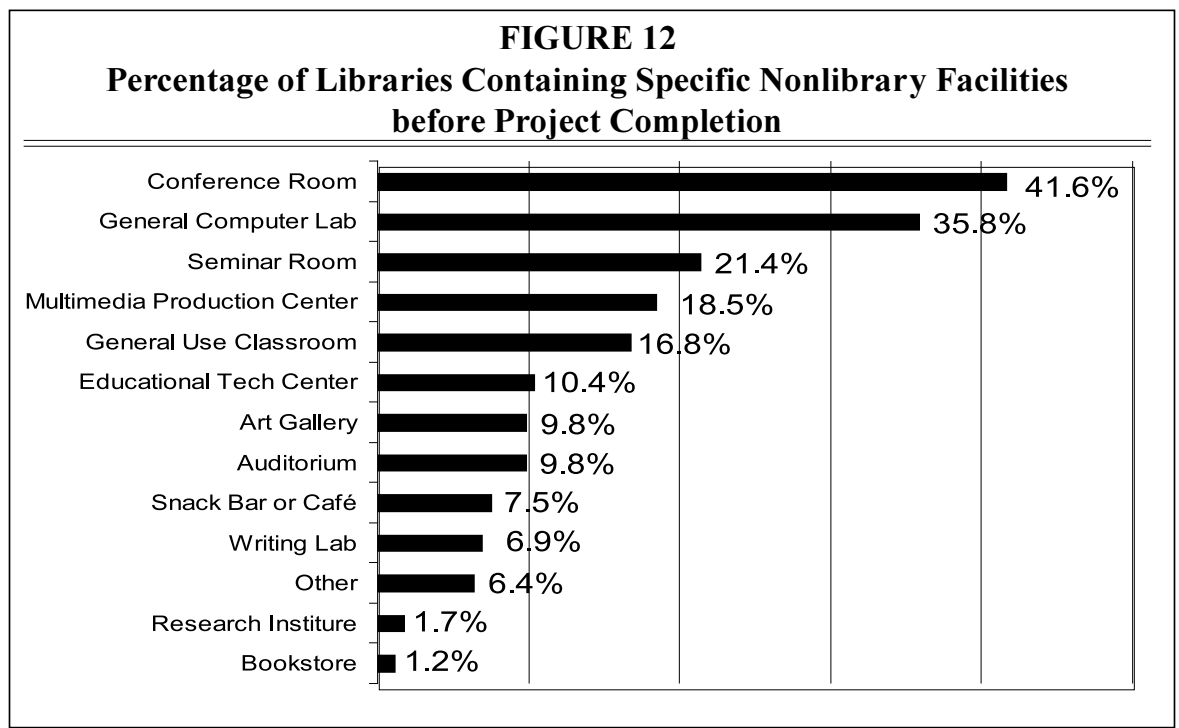

ence of art galleries, auditoriums, or educational technology centers in more than 20 percent of the postproject libraries was not anticipated. The abundance of postproject libraries housing classrooms, seminar rooms, and writing labs also is impressive.

The trend toward inclusion of nonlibrary facilities within the building has changed the character of the postproject library in significant ways. Rather than having a few nonlibrary units occasionally occupying space in the building, the physical library is becoming the home base for a wide variety of operations. As such, it is becoming a more complex facility, one that both attracts students for multiple purposes and may assume additional responsibilities to accommodate nonlibrary services. Clearly, the inclusion of nonlibrary facilities is becoming a standard feature of recently im-

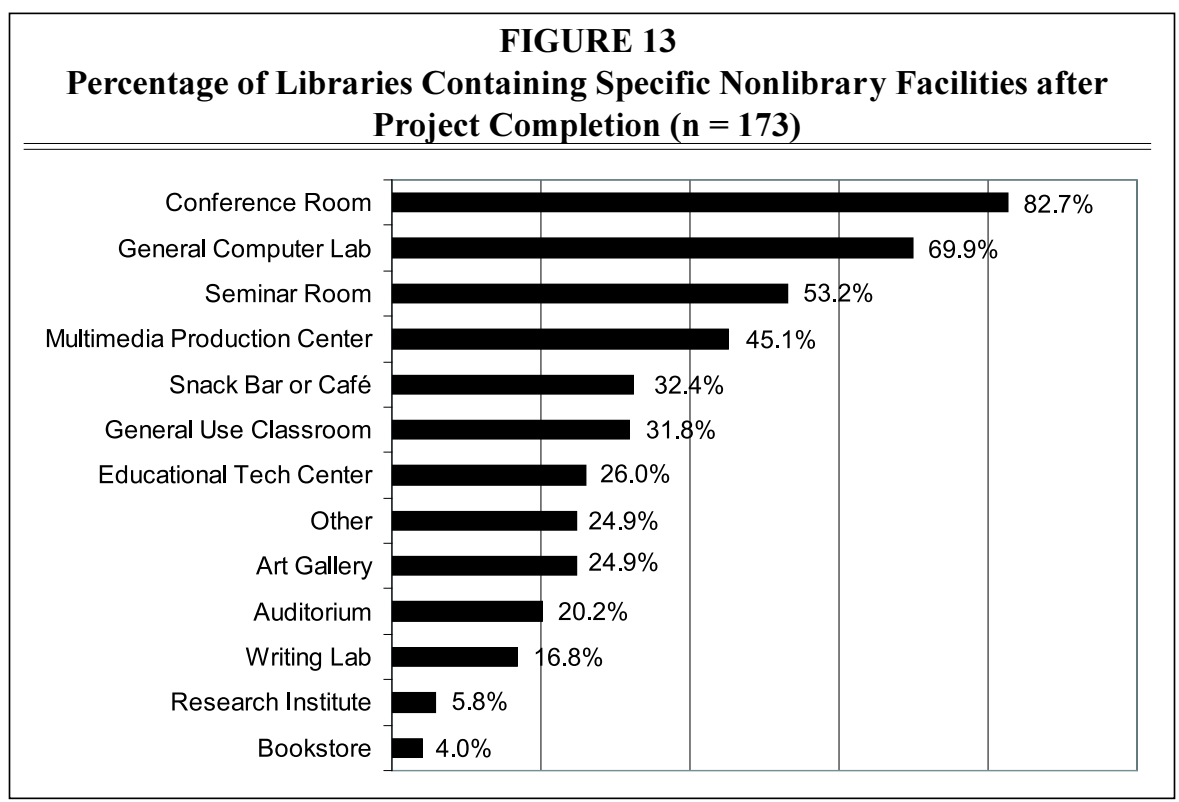


proved libraries. The true stand-alone library is fading from the scene as new facilities are erected and older ones are expanded, renovated, and reconfigured.

\section{Findings: Facility Quality}

A final set of questions addressed facility quality and "owner" (i.e., librarian) satisfaction with libraries before and after project completion. The responses to these questions were expected to indicate the degree of facility improvement resulting from the project. The investigators also expected to identify areas where architects had been most successful and least successful in improving facility quality.

Tables 7 and 8 report librarian assessments of both overall facility quality and the quality of specific features most associated with user satisfaction. As shown in table 7, preproject dissatisfaction was clearly greatest with library instruction labs and heating, ventilation, and air conditioning (HVAC) systems, with respective "poor" ratings of 58.7 and 52.1 percent for those facilities. More than 40 percent of the respondents also rated collection storage, telecommunication systems, user seating, and natural lighting as "poor." Survey participants reported the least degree of dissatisfaction with the location of service points, with 22 percent actually regarding them as "very good." However, the preponderance of "poor" and "fair" ratings indicates that these facility features were seriously deficient in most preproject libraries.

How well did the architects, contractors, and librarians succeed in delivering an improved facility? Table 8 indicates that they were most successful in addressing user seating, public access workstation, and telecommunication needs, with each of these factors receiving "excellent" ratings from more than 60 percent of the respondents. Instruction lab solutions also were well received, with 87.8 percent of the participants rating this teaching facility as either "excellent" or "very good." More than 50 percent of the responses also indicated that natural lighting (59.3\%) and collection storage results were "excellent."

Consistent with researcher expectations, the facility planners were least successful in providing a suitable HVAC system. Although virtually no respondents $(0.6 \%)$ rated their HVAC systems as "excellent" before the project, only 26.9 percent gave this rating to the heating and air system after the project was completed. Also, respondents gave their postproject HVAC systems the highest percentage of "good" $(27.5 \%)$ and "fair" $(9.6 \%)$ ratings among the ten variables.

TABLE 7

Preproject Quality of Library Facility (N range = 143-163)

\begin{tabular}{|c|c|c|c|c|c|}
\hline \multirow{2}{*}{$\begin{array}{l}\text { Preproject Quality } \\
\text { of Library Facility }\end{array}$} & \multicolumn{5}{|c|}{ Response Percentage } \\
\hline & Excellent & Very good & Good & Fair & Poor \\
\hline Layout/ease of navigation & $2.5 \%$ & $11.0 \%$ & $19.0 \%$ & $29.4 \%$ & $38.0 \%$ \\
\hline Location service points & $3.1 \%$ & $22.0 \%$ & $28.9 \%$ & $28.9 \%$ & $17.0 \%$ \\
\hline Instruction lab/e-classroom & $2.8 \%$ & $4.9 \%$ & $9.8 \%$ & $23.8 \%$ & $58.7 \%$ \\
\hline User seating/work space & $2.5 \%$ & $3.1 \%$ & $16.6 \%$ & $33.7 \%$ & $44.2 \%$ \\
\hline Collection storage & $1.2 \%$ & $5.5 \%$ & $13.4 \%$ & $30.5 \%$ & $49.4 \%$ \\
\hline Public access workstations & $1.9 \%$ & $4.3 \%$ & $18.5 \%$ & $38.3 \%$ & $37.0 \%$ \\
\hline Telecommunications & $1.9 \%$ & $6.8 \%$ & $13.6 \%$ & $30.9 \%$ & $46.9 \%$ \\
\hline Artificial light & $2.5 \%$ & $5.5 \%$ & $19.0 \%$ & $42.9 \%$ & $30.1 \%$ \\
\hline Natural light & $3.7 \%$ & $10.5 \%$ & $20.4 \%$ & $24.1 \%$ & $41.4 \%$ \\
\hline HVAC & $0.6 \%$ & $1.2 \%$ & $19.0 \%$ & $27.0 \%$ & $52.1 \%$ \\
\hline Overall ambience & $2.5 \%$ & $1.2 \%$ & $18.0 \%$ & $34.2 \%$ & $44.1 \%$ \\
\hline
\end{tabular}

*Note: Percentages in rows may not equal $100.0 \%$ due to rounding. 
TABLE 8

Post-Project Facility Quality (N range $=164-169)$

\begin{tabular}{lccccc} 
Preproject Quality & \multicolumn{5}{c}{ Response Percentage } \\
of Library Facility & Excellent & Very good & Good & Fair & Poor \\
\hline Layout/ease of navigation & $43.8 \%$ & $37.3 \%$ & $17.8 \%$ & $1.2 \%$ & $0.0 \%$ \\
Location service points & $47.9 \%$ & $40.2 \%$ & $10.1 \%$ & $1.8 \%$ & $0.0 \%$ \\
Instruction lab/e-classroom & $57.9 \%$ & $29.9 \%$ & $8.5 \%$ & $3.0 \%$ & $0.6 \%$ \\
User seating/work space & $68.6 \%$ & $23.1 \%$ & $5.9 \%$ & $2.4 \%$ & $0.0 \%$ \\
Collection storage & $51.5 \%$ & $24.0 \%$ & $18.6 \%$ & $4.8 \%$ & $1.2 \%$ \\
Public access workstations & $65.7 \%$ & $26.0 \%$ & $7.7 \%$ & $0.6 \%$ & $0.0 \%$ \\
Telecommunications & $60.4 \%$ & $32.5 \%$ & $5.9 \%$ & $1.2 \%$ & $0.0 \%$ \\
Artificial light & $43.8 \%$ & $33.7 \%$ & $18.9 \%$ & $2.4 \%$ & $1.2 \%$ \\
Natural light & $59.3 \%$ & $24.6 \%$ & $13.2 \%$ & $1.2 \%$ & $1.8 \%$ \\
HVAC & $26.9 \%$ & $34.7 \%$ & $27.5 \%$ & $9.6 \%$ & $1.2 \%$ \\
Overall ambience & $70.4 \%$ & $24.3 \%$ & $5.3 \%$ & $0.0 \%$ & $0.0 \%$ \\
*Note: Percentages in rows may not equal $100.0 \%$ due to rounding. & & \\
\hline
\end{tabular}

Although the quality of HVAC systems was clearly improved after the project was done, the level of postproject satisfaction fell well below that found for the other variables reported.

Survey respondents also assessed the overall ambience of their facilities both before project implementation and after facility improvements were completed. Of the participants, 78.3 percent regarded their preproject facility ambience as either "fair" or "poor," compared to only 3.7 percent who gave it a rating of "very good" or "excellent." Clearly, these facilities were in need of major environmental improvement as well as space and technology enhancement.

In contrast, respondent assessments of the postproject library ambience were consistently positive, with 70.4 percent assigning an "excellent" rating and 94.7 percent considering the facility ambience either "excellent" or "very good." Significantly, no respondents rated their postproject facility ambience as either "fair" or "poor." As a result, despite HVAC shortcomings, the respondents appeared satisfied that their facility planning efforts had created a more comfortable, functional, userfriendly environment. This is a significant finding because some respondents in a 182-respondent survey would normally be expected to express dissatisfaction with project results.
As a result of this finding, it appears reasonable to conclude that the building projects covered in this study were successful in producing learning environments meeting or exceeding librarian expectations. The high frequency of "excellent" and "very good" ambience ratings indicates that the projects did make a major difference in library facility quality. It is statistically improbable that this pattern of responses could occur by chance.

\section{Study Findings and Significance}

Despite differences in institutional setting, project type, and project scale, it is possible to discern several important trends and directions in academic library facility improvements during the 19952002 period.

\section{Major Conclusions}

First, contrary to the views of some pessimists, academic library building activity has not diminished in recent years. In fact, the pattern of activity was remarkably stable during the study period, with identified activity reaching its highest point in 2002.

The most common project types were new facilities (43.1\%, including $13.3 \%$ in multipurpose buildings) and addition/ renovation projects $(42.0 \%)$. Additiononly and renovation-only projects were 
less frequent. Also, the University of Maryland and several other institutions have "re-purposed" existing facilities to permit new uses. Despite some writers' contentions that space requirements have diminished, the size of improved library facilities has increased in all cases except renovations, with doubling or tripling of existing building size common in many smaller institutions.

There were more significant facility projects, in relation to institutional population size, in public institutions than in private institutions. Projects were completed more often in doctoral/research and master's institutions than in baccalaureate and associate degree colleges.

Although the number of libraries in multipurpose facilities did not increase, the presence of special facilities increased dramatically in the postproject libraries. More than one-half of the 182 responding libraries reported having conference rooms, general computer labs, and seminar rooms following project completion. The greatest type of facility increase was found for cafes or snack bars. All twelve types of special facility occurred with greater frequency in the postproject library than the preproject building.

Major technology upgrades were implemented in most building projects. Most libraries reported using UTP category 5 , category 6 , or fiber-optic wiring to the desktop.

Of the responding libraries, 51.7 percent had 250 or more data ports following project completion. The number of public access workstations increased significantly, as did the number of computers in library instruction labs. Wireless network access, available in only seven percent of the preproject libraries, was found in 52.6 percent of these facilities after project completion.

The responding libraries reported significant advances in the number and type of user spaces. The amount of general user seating was increased in all types of libraries, and major investments in group study rooms were made. Nearly threequarters of the participating libraries lacked any wired seating for users before facility improvement. After project completion, more than 59 percent of these libraries provided wired network access from at least one-quarter of their user seats and 12.3 percent delivered wired access at 100 percent of all seating

Similar advances were made in the provision of wireless network access, although this option became viable primarily in the latter years of the study period. More libraries (24.6\%) delivered wireless than wired access to all seats following project completion, although wireless penetration diminished sharply among libraries providing network access at less than 100 percent of their seating spaces.

Provisions for print collection growth varied significantly, with some libraries securing more than thirty years of growth capacity and others already facing shelf space crises. Compact shelving was used extensively to increase the on-site collection capacity of existing buildings. It also has been used increasingly as an integral part of new and expanded facility plans to stretch shelf capacity within a finite space, thereby freeing valuable library space for other uses. Off-site storage was used by 27.3 percent of the responding libraries.

Architects and librarians have demonstrated a clear preference for softer, carpeted floor surfaces in the improved libraries, with softer, "cool" colors supplanting orange and earth tones as the predominant carpet colors. Wall colors were generally neutral, with white and beige emerging as the colors of choice.

Overall facility quality was improved profoundly in all types of library projects. Prior to project completion, none of the eleven building features selected to indicate facility quality received "excellent" ratings from more than 3.7 percent of the respondents. With the exception of HVAC systems $(26.9 \%)$, no facility quality element received an "excellent" rating lower than 43.8 percent in the postproject libraries. The "excellent" ratings for overall ambience improved from 2.5 to 70.4 percent after the building was done. Clearly, 
facility quality has improved profoundly in the participating libraries.

\section{Significance of Findings}

Where significant library building projects have been completed, students, faculty members, and librarians have experienced a very different postproject building. The finished facilities are generally larger, have greater seating and collection storage capacities, provide a greater number of computers for end users, allow for collaborative learning in dedicated rooms, contain instruction labs with hands-on learning resources, and provide network access (wired and/or wireless) at many or all public seating locations. The majority of them include special facilities (computer labs, snack bars, multimedia production centers, etc.) that enable a greater range of activities to occur under the library's roof and/or provide increased user comfort and convenience.

These facilities also provide a vastly improved ambience that encourages use, rather than avoidance, of the library building. They still are located near other academic facilities and along major pedestrian traffic routes. In many cases, they have become showpiece facilities for their parent institutions. Often they have made the library an on-campus leader in technology implementation. In most cases, they have provided a technologically advanced learning environment where print, nonprint, and electronic resources can be used simultaneously for individual or group research at multiple locations throughout the building.

The ultimate test for these facilities, of course, is the amount and type of usage they are receiving. Usage findings from this study will be reported in the companion article. However, it is clear that most libraries included in this survey have created a different type of facility, one clearly identifiable as a library while also infusing new technology and user requirements into a physical setting. These "hybrid print/electronic libraries" are positioned to address evolving teaching and learning needs well into the fu- ture. Although usage ultimately reflects many factors, including library service quality and curricular change, a robust physical facility provides a platform from which libraries have the opportunity to remain vital, pivotal participants in the academic enterprise.

\section{Implications for Further Research}

Academic libraries are complex social institutions with an evolving educational mission. The full range of their activities and impact is not always grasped by other members of the academic communityor sometimes by librarians themselves.

There is considerable interest in the "library as place" among academic librarians today. Recent CLIR/DLF and OCLC studies have focused on changes in information-seeking behaviors within the academic community. Librarians are becoming increasingly aware of the Pew Internet \& American Life Project's ongoing series of reports on many facets of Internet use. Nicholas C. Burckel is studying the impact of digital technologies on library buildings. ${ }^{63}$ Working with a CLIR grant, Scott Bennett has surveyed directors of libraries completing recent projects to identify patterns in space-planning practices. ${ }^{64}$

At present, there are abundant opportunities for research about academic library buildings and their users. Librarians need to know more about space needs for current and emergent technologies. Greater knowledge is needed about the actual use of various types of space within both older and newer libraries. Postoccupancy assessment studies are desirable to identify patterns of building success and failure, including the obsolescence of certain facilities.

The building component needs to be factored more actively into studies of student information seeking. Patterns of facility use and nonuse across disciplinary lines need to be identified. Student, faculty, and administrator perceptions of library facilities need to be better understood. The "politics of the building process" requires greater attention. Studies 
comparing library facility use with student use of other "places" (residence halls, classrooms, student unions, bookstores, coffee bars) will provide greater understanding of user choices and contribute to user-sensitive facility planning.

This article should contribute to existing knowledge about "the library as place" and to the planning of successful facilities. By identifying the types of libraries built between 1995 and 2002, it provides valid, empirical evidence of academia-wide activity patterns in an area where systematic knowledge has been lacking. By providing such evidence, it helps advance research and discussion about the physical library, both present and future, beyond the realm of anecdote and speculation. This article also should have a practical benefit, assisting librarians and facility planners to plan new and improved academic libraries with systematic knowledge of the initiatives undertaken since 1994.

Paired with the forthcoming, companion article comparing usage patterns in pre- and postproject libraries, this article also should contribute to a broader understanding of physical spaces on campus in a technological age. Administrators and librarians face difficult choices among legitimate competing interests in the years ahead. The findings from this study should contribute toward the selection of choices enhancing student learning experiences in an uncertain future.

\section{Notes}

1. Robert F. Munn introduced the term bottomless pit several decades ago to describe many administrators' perceptions that the library was an insatiable source of growing resource demands because librarians were unable to place any limits on their collection needs; see Munn, "The Bottomless Pit, or the Academic Library as Viewed from the Administration Building," College E Research Libraries 29 (Jan. 1968): 51-54. See also Larry Hardesty, "The Bottomless Pit Revisited," College $\mathcal{E}$ Research Libraries 52 (May 1991): 219-30, for confirmation that many academic administrators still regarded the library as a source of unreasonable demands even before the 1990s upsurge in technology expenditures.

2. Florence Olsen, "Colleges Expect to Increase Information-Technology Spending by 5\%," Chronicle of Higher Education (Mar. 26, 2003): Electronic edition. Available online from http:/ / chronicle.com/free/2003/03/2003032601t.htm. [Cited 25 June 2003.]

3. For a discussion of technological and comfort improvements in student residences, see Scott Baltic, "Designer Dorms," University Business 4 (Sept. 2001): 34-41: 70-71.

4. Scott Carlson, "Colleges Struggle with a 60's Legacy: Ugly, Wasteful, and Outdated Buildings," Chronicle of Higher Education 47 (Aug. 17, 2001): A23-A25.

5. See Walter A. Brown and Cayo Gamber, Cost Containment in Higher Education: Issues and Recommendations, ASHE-ERIC Higher Education Report, vol. 28, no. 5 (San Francisco: JosseyBass, 2002), 50-55, for a discussion of deferred maintenance issues and options.

6. Jeffrey Selingo, "The Disappearing State in Public Higher Education," Chronicle of Higher Education 49 (Feb. 28, 2003): A22-A25.

7. Statement made by Gene Levy, provost of Rice University, in presentation, "Provosts' Perspective on Library Architecture," 3rd ARL/OCLC Strategic Issues Forum, Future Library Architecture: Conception, Design and Use of Library Space, Las Vegas, Nev., Feb. 16, 2002.

8. Leonard Kniffel, "Cal State U. Freezes Construction to Ponder 'Virtual Library,'” American Libraries 24 (Sept. 1993): 692, 694.

9. Jean Seligman, “Jarvis Keeps Battling Taxes," Newsweek, 5 Oct. 1981, p. 12B. [Cited 27 June 2003 on Lexis-Nexis ${ }^{\mathrm{TM}}$.]

10. David L. Wilson, "New California State Campus Has Ambitious Plans for Technology," Chronicle of Higher Education 43 (Oct. 18, 1996): A23-A24. For further information on the reversal of this decision and subsequent development of the CSUMB libraries, see John Ober, "Library Services at California State University, Monterey Bay," in Building Libraries for the 21st Century: The Shape of Information, ed. T. D. Webb (Jefferson, N.C.: McFarland, 2000): 122-37.

11. Bill Robnett, "Re: Study of Facility Quality and Academic Library Usage," e-mail to Harold B. Shill, March 4, 2003.

12. Steve Jones, et al., "The Internet Goes to College: How Students Are Living the Future with Today's Technology." September 15, 2002. [Cited 17 September 2002.] Available online from http:/ / www.pewinternet.org. 
13. Stephen Merritt, “The Millenials: A Perspective on America's Next Generation and Their Impact on Higher Education," Associated College Libraries of Central Pennsylvania Fall Conference, Harrisburg, Pa., October 18, 2002.

14. The 1995-2001 trend data were extracted from a table showing 1986-2001 ARL library usage data in ARL Statistics, 2000-01, comp. and ed. Martha Kyrillidou and Mark Young (Washington, D.C.: Association of Research Libraries, 2002), 7.

15. American Association of Health Sciences Libraries, Annual Statistics of Medical School Libraries in the United States and Canada, 2000-01, 24th ed. (Seattle: AAHSL, 2002), xxiv.

16. Donald E. Riggs, "New Libraries Remain an Excellent Investment," College E Research Libraries 63 (Mar. 2002): 109.

17. Scott Carlson, "The Deserted Library," Chronicle of Higher Education 48 (Nov. 16, 2001): A35-A38.

18. Jeff Morris, "The College Library in the New Age," University Business 5 (Oct. 2002): 2629 , contains a panel discussion of the diverse social roles occupied by new and renovated libraries. A second article, Jeff Morris, "History Meets State of the Art," University Business 5 (Oct. 2002): 31-35, describes the usage of a new stand-alone library at Illinois Wesleyan University and a science library placed strategically in a larger science center at Williams College.

19. Alice Harrison Bahr, "Library Buildings in a Digital Age, Why Bother?" College E Research Libraries News 61 (July/Aug. 2000): 590-91, 608. 150.

20. "King's College Library Wins Award," College \& Research Libraries News 59 (Mar. 1998):

21. Dalia Hagan, "Directory of Completed Academic Library Building Projects, 1995-2002," e-mail to Harold B. Shill, October 9, 2002.

22. Andrew Richard Albanese, "Deserted No More," Library Journal 128 (Apr. 11, 2003): 34-36.

23. Michael K. Buckland, Book Availability and the Library User (New York: Pergamon, 1975).

24. Allen Kent, Jacob Cohen, et al., Use of Library Materials: The University of Pittsburgh Study (New York and Basel: Marcel Dekker, 1979).

25. Charles B. Osburn, Academic Research and Library Resources: Changing Patterns in America (Westport, Conn., and London: Greenwood Pr., 1979).

26. Ethelene Whitmire, "The Relationship between Undergraduates' Background Characteristics and College Experiences and Their Academic Library Use," College E Research Libraries 62 (Nov. 2001): 528-40; _ "Cultural Diversity and Undergraduates' Academic Library Use," Journal of Academic Librarianship 29 (May 2003): 148-61; Ruth C. Shoge, "The Library as Place in the Lives of African Americans," in Learning to Make a Difference: Proceedings of the Eleventh National Conference of the Association of College E Research Libraries, April 10-13, 2003, Charlotte, N.C., ed. Hugh A. Thompson (Chicago: ACRL, 2003): 161-69.

27. John Lubans Jr., "How First-year University Students Use and Regard Internet Resources" (Durham, N.C.: Duke University Library, April 8, 1998). [Cited 21 February 1999.] Available online from http:/ / www.lubans.org/docs/1styear/firstyear.html.

28. For Internet use patterns among high school students in the 15-17 age group, see Pew Internet \& American Life Project, "The Internet and Education: Findings of the Pew Internet and American Life Project," September 1, 2001. [Cited 15 September 2001.] Available online from http:/ / www.pewinternet.org. See Jones, et al, "The Internet Goes to College," for 2002 data on technology adoption by college students.

29. Cynthia Gal, et al., "Territoriality and the Use of Library Study Tables," Perceptual and Motor Skills 63 (1986): 567-74; Paul W. Grimes and Marybeth F. Charters, "Library Use and the Undergraduate Economics Student," College Student Journal 34 (Dec. 2000): 557-70; Joy K. Pothoff, et al., "An Evaluation of Patron Perceptions of Library Space Using the Role Repertory Grid Procedure," College E Research Libraries 61 (May 2000): 191-203; Lemuel W. Wilson, "How Do Students' Perceptions of Their Library Usage Influence Their Educational Outcomes?" College Student Journal 35 (Sept. 2001): 366-72.

30. Roberto Delgadillo and Beverly P. Lynch, "Future Historians: Their Quest for Information," College E Research Libraries 60 (May 1999): 245-60.

31. Virginia E. Young, "Can We Encourage Learning by Shaping Environment? Patterns of Seating Behavior in Undergraduates," pp. 161-69 in Learning to Make a Difference: Proceedings of the Eleventh National Conference of the Association of College $\mathcal{E}$ Research Libraries, April 10-13, 2003, Charlotte, N.C., ed. Hugh A. Thompson (Chicago: ACRL, 2003).

32. Juris Dilevko and Lisa Gottlieb, "Print Resources in an Electronic Age: A Vital Part of the Research Process for Undergraduate Students," Journal of Academic Librarianship 28 (Nov. 2002): 381-92.

33. Philip M. Davis, "The Effect of the Web on Undergraduate Citation Behavior," College $\mathcal{E}$ Research Libraries 63 (Jan. 2000): 53-60; Deborah J. Grimes and Carl H. Boening, "Worries with the Web: A Look at Student Use of Web Resources," College E Research Libraries 62 (Jan. 2001): 11-24; 
Xue-Ming Bao, "A Comparative Study of Library Surveys of Internet Users at Seton Hall University in 1998 and 2001," College \& Research Libraries 63 (May 2002): 251-59.

34. Terrence F. Mech and Charles I. Brooks, "Anxiety and Confidence in Using a Library by College Freshmen and Seniors," Psychological Reports 81 (Dec. 1997): 929-30; see also Anthony J. Ongwuegbuzie and Qun G. Jiao, "I'll Go to the Library Later: The Relationship between Academic Procrastination and Library Anxiety," College E Research Libraries 61 (Jan. 2000): 45-54.

35. Amy Friedlander, Dimensions and Use of the Scholarly Information Environment: Introduction to a Data Set (Washington, D.C.: Digital Library Federation and Council on Library and Information Resources, 2002). A shorter summary of major study findings is available in Daniel Greenstein and Leigh Watson Healey, "National Survey Documents Effects of Internet Use on Libraries," CLIR Issues, no. 27 (May/June 2002). [Cited 5 May 2003.] Available online from www.clir.org/ pubs/issues/issues27.html.

36. Leigh Watson Healy, "The Voice of the User: Where Students and Faculty Go for Information," EduCause 2002 Conference, Atlanta, Oct. 2, 2002.

37. OCLC, "How Academic Librarians Can Influence Students' Web-based Information Choices," OCLC white paper on the information habits of college students (Dublin, Ohio: OCLC, 2002). [Cited 6 July 2003.] Available online from http://www2.oclc.org/oclc/pdf/ printondemand/informationhabits.pdf.

38. See, for example, Elizabeth Chamberlain Habich, Moving Library Collections: A Management Handbook (Westport, Conn.: Greenwood Pr., 1998); Carol R. Brown, Interior Design for Libraries: Drawing on Function and Appeal (Chicago and London: ALA, 2002); Jeannette Woodward, Countdown to a New Library: Managing the Building Project (Chicago and London: ALA, 2000).

39. Richard J. Bazillion and Connie L. Braun, Academic Libraries as High-tech Gateways: A Guide to Design and Space Decisions, 2nd ed. (Chicago and London: ALA, 2001). The second edition of this work substantially updates the similarly excellent first edition of the same title published by ALA in 1995.

40. Michael J. Crosbie and Damon D. Hickey, When Change Is Set in Stone: An Analysis of Seven Academic Libraries Designed by Perry Dean Rogers \& Partners, Architects (Chicago: ACRL, 2001).

41. Philip D. Leighton and David C. Weber, Planning Academic and Research Library Buildings, 3rd ed. (Chicago: ALA, 2000).

42. William W. Sannwald, Checklist of Library Building Design Considerations, 4th ed. (Chicago and London: ALA, 2001).

43. The two most recent annual compilations are Bette-Lee Fox, “The Building Buck Doesn't Stop Here," Library Journal 127 (Dec. 2002): 42-55, and "Building for the Future," American Libraries 34 (Apr. 2003): 40-62.

44. Dennis C. James and Sharon L. Stewart, "Library Design Analysis Using Post-occupancy Evaluation Methods," Science \& Technology Libraries 15 (1995): 3-15.

45. Anita Lowry, "The Information Arcade at the University of Iowa," CAUSE/EFFECT 17 (Fall 1994): 38-44; Donald Beagle, "Conceptualizing an Information Commons," Journal of Academic Librarianship 25 (March 1999): 82-89; Allison Cowgill, Joan Beam, and Lindsey Wess, "Implementing an Information Commons in a University Library," Journal of Academic Librarianship 27 (Nov. 2001): 432-39; Russell Bailey and Barbara Tierney, "Information Commons Redux: Concept, Evolution, and Transcending the Tragedy of the Commons," Journal of Academic Librarianship 28 (Sept. 2002): 277-86; Donald Beagle, "Extending the Information Commons: From Instructional Testbed to Internet2," Journal of Academic Librarianship 28 (Sept. 2002): 287-96. 1996).

46. Library Buildings, Equipment and the ADA: Compliance Issues and Solutions (Chicago: ALA,

47. Shelley Heaton and Kenneth E. Marks, "Planning the UNLV Lied Library," Library Hi Tech 20 (2002): 12-20; Myoung-ja Lee Kwon and Kenneth E. Marks, "Construction of the Lied Library," Library Hi Tech 20 (2002): 21-32; Jason Vaughan, "Preparing for Technology: Systems Planning and Implementation in Lied Library," Library Hi Tech 20 (2002): 33-46; Richard J. Bazillion, "The Wisdom of Hindsight: A New Library One Year Later," American Libraries 32 (Apr. 2001): 72-74; Frieda O. Weise and M. J. Tooey, "The Health Sciences and Human Services Library: This Is One Sweet Library," Bulletin of the Medical Library Association 87 (Apr. 1999): 170-77; Jeannette Woodward, "The Tale of the Terribly High-tech Library Building," American Libraries 26 (Apr. 1995): 308-10; Ronald Litke, "Building a Dream," University Business 2 (Nov. 1999): 38-45.

48. See, for example, Drew Harrington, "Six Trends in Library Design," Library Journal (Dec. 2001): 12-14 (Buyer's Guide Issue); Jeffrey Scherer, "Light and Libraries," Library Hi Tech 17 (1999): 358-71; Richard Boss, "Facilities Planning for Technology," Library Technology Reports 31 (July/ Aug. 1995): 389-483; Lamar L. Veatch, "Toward the Environmental Design of Library Buildings," Library Trends 36 (1987): 361-76; Denelle Wrightson and John M. Wrightson, "Acoustical Considerations in Planning and Design of Library Buildings," Library Hi Tech 17 (1999): 349-57.

49. F. W. Lancaster, Toward Paperless Information Systems (New York: Academic Pr., 1978). 

49.

50. C. William Day, "The Library of the Future," American School E University (Sept. 1998): 48-

51. Laverna Saunders, "The Virtual Library Today," Library Administration and Management 6 (spring 1992): 66-70.

52. Walt Crawford and Michael Gorman, Future Libraries: Dreams, Madness E Reality (Chicago and London: ALA, 1995); Crawford, "Paper Persists: Why Physical Library Collections Still Matter," Online 22 (Jan. /Feb. 1998): 42-48; __, "Library Space: The Next Frontier," Online 23 (Mar./Apr. 1999): 61-62+; , Being Analog: Creating Tomorrow's Libraries (Chicago and London: ALA, 1999); Gorman, Our Enduring Values: Librarianship in the 21st Century (Chicago and London: ALA, 2000).

53. Neil Gershenfeld, When Things Start to Think (New York: Henry Holt and Co., 1999).

54. Sam Demas and Jeffrey Scherer, "Esprit de Place," American Libraries 33 (Apr. 2002): $65-69$.

55. Fox, "The Building Buck Doesn't Stop Here," 42-55.

56. Comprehensive Carnegie classification listings are available online at the Carnegie Foundation for the Advancement of Teaching Web site, http:/ / www.carnegiefoundation.org.

57. This issue is discussed at length in Charles W. Bailey Jr., "Brick, Bytes or Both? The Probable Impact of Scholarly Electronic Publishing on Library Space Needs," in Information Imagineering: Meeting at the Interface, ed. Milton T. Wolf, Pat Ensor, and Mary Augusta Thomas (Chicago and London: ALA, 1998): 89-99.

58. The Pennsylvania State University, Faculty Advisory Committee on Academic Computing, FACAC Student Survey 2002 (University Park, Pa.: The Pennsylvania State University, 2002).

59. For further discussion, see Mary Augusta Thomas, "Redefining Library Space: Managing the Co-existence of Books, Computers and Readers," Journal of Academic Librarianship 26 (Nov. 2000): 408-15.

60. The large-scale cancellation project at Drexel University has been observed with considerable interest by academic librarians. For an initial description of the migration to an "all-electronic collection," see Carol Hansen Montgomery, "Print to Electronic: Measuring the Operational and Economic Implications of an Electronic Journal Collection," Learned Publishing 15 (Apr. 2002): 129-36. For an update on that project, see Carol Hansen Montgomery and Donald W. King, "An 'All' Electronic Journal Collection in a University Library: Two Years Later," in Learning to Make a Difference: Proceedings of the Eleventh National Conference of the Association of College $\mathcal{E}$ Research Libraries, ed. Hugh A. Thompson (Chicago: ACRL, 2003): 116-20.

61. Susan Carol Curzon, "When Disaster Strikes: The Fall and Rise of a Library," American Libraries 31 (Apr. 2000): 64-69.

62. The political advantages of strategically selected partnerships are considered in Harold B. Shill, "Strategic Positioning and the Building Project: Penn State Harrisburg's Library of the Future," in Racing toward Tomorrow: Proceedings of the Ninth National Conference of the Association of College $\mathcal{E}$ Research Libraries, ed. Hugh A. Thompson (Chicago: ACRL, 1999): 370-79.

63. Nicholas C. Burckel, "Library Space in the Digital Age," Kanazawa Institute of Technology Roundtable, Kanazawa, Japan, July 3, 2003.

64. Scott Bennett, "Survey of Recent Library Space Planning Practices," Council on Library and Information Resources, Sept. 2002. 